CIRJE-F-1108

\title{
Inflation Target and Anchor \\ of Inflation Forecasts in Japan
}

\author{
Shin-ichi Fukuda \\ The University of Tokyo \\ Naoto Soma
}

The University of Tokyo

January 2019

CIRJE Discussion Papers can be downloaded without charge from:

http://www.cirje.e.u-tokyo.ac.jp/research/03research02dp.html

Discussion Papers are a series of manuscripts in their draft form. They are not intended for circulation or distribution except as indicated by the author. For that reason Discussion Papers may not be reproduced or distributed without the written consent of the author. 


\title{
Inflation Target and Anchor of Inflation Forecasts in Japan ${ }^{*}$
}

\section{Shin-ichi Fukuda (University of Tokyo) and Naoto Soma (University of Tokyo) ${ }^{* *}$}

\begin{abstract}
In literature, a number of studies argued that an explicit inflation targeting regime provides less uncertainty about future inflation rates through anchoring expectations. However, it is far from clear whether the argument still holds true when the central bank faces a serious difficulty in achieving the target. The Bank of Japan (BOJ) is a central bank that has adopted an explicit inflation target but faced a serious difficulty in achieving it. The purpose of this paper is to explore whether the explicit inflation targeting regime could anchor inflation expectations in Japan. In the analysis, we estimate panel Phillips curves by using Japanese forecaster-level data of "ESP Forecast”. We find significant structural changes in how to form inflation expectations. Before the BOJ announced the $2 \%$ inflation target, the estimated anchor of inflation expectations was negative. The new target increased the estimated anchor to significant positive values. This suggests that the BOJ's explicit inflation target could partly anchor inflation expectations. However, the estimated anchor has never reached the target. More importantly it started to decline when it turned out that the $2 \%$ target would not be feasible in the short-run. This implies that an explicit inflation targeting needs to be a feasible one to anchor inflation expectations persistently.
\end{abstract}

JEL code: E58, E31, E37

Key words: Inflation target, The Bank of Japan, Unconventional monetary policy

\footnotetext{
* An earlier version was presented at the 85th International Atlantic Economic Conference in London and the monthly finance workshop at Development Bank of Japan. We would like to thank participants for valuable comments. This research was supported by JSPS KAKENHI Grant Number 17K18557 and by the Center for Advanced Research in Finance (CARF) in the University of Tokyo.

** Correspondence address: Shin-ichi FUKUDA, Faculty of Economics, University of Tokyo, 7-3-1 Hongo Bunkyo-ku Tokyo 113-0033, JAPAN. E-mail: sfukuda@e.u-tokyo.ac.jp.
} 


\section{Introduction}

In literature, a number of studies argued that an explicit inflation targeting regime provides less uncertainty about future inflation rates than a monetary policy regime without explicit numerical inflation target because it anchors expectations successfully (see, for example, Bernanke et al. [1999]) ${ }^{1}$. However, the argument was based on an implicit assumption that the central bank can achieve the explicit inflation target appropriately. Thus it is far from clear whether the argument still holds true when the central bank faces a serious difficulty in achieving its explicit inflation target. Under prolonged deflation, the Bank of Japan (BOJ) is a central bank that has adopted an explicit inflation target but faced a serious difficulty in achieving the target. The purpose of this paper is to explore to what extent the BOJ's explicit inflation target could anchor inflation expectations successfully under the special environments in Japan.

Soon after the BOJ announced the $2 \%$ inflation target in the consumer price index (CPI) in January 2013, the CPI inflation rate, which had stagnated below zero for a long time, rose substantially. In April 2014, it reached 1.5\% when excluding fresh food but including energy and $0.8 \%$ when excluding food and energy. However, it started to decline in the latter half of 2014 when excluding the direct effects of consumption tax hikes. Reflecting oil price decline, it fell below zero in July 2015 when excluding fresh food but including energy. Even when excluding food and energy, it fell below zero in February 2017 (Figure 1). It is thus likely that the role of the explicit inflation target might have faced substantial structural changes in anchoring inflation expectations in Japan.

To explore possible structural changes, the following analysis assumes that professional forecasters apply an expectations-augmented Phillips curve when they forecast macroeconomic variables in Japan. $^{2}$ We then estimate panel Phillips curves by using Japanese forecaster-level data of "ESP Forecast" which is collected by Japan Center of

\footnotetext{
1 Gürkaynak et al. (2010) found that inflation expectations had been more firmly anchored in the United Kingdom -a country with an explicit inflation target- than in the United States -a country with no such target- using the difference between far-ahead forward rates on nominal and inflation-indexed bonds. Using evidence from financial markets and surveys of professional forecasters, Beechey et al. (2011) showed that long-run inflation expectations were more firmly anchored in the euro area than in the United States because a quantitative inflation target could help provide a firmer anchor.

2 Using survey data from six Asian-Pacific countries, Rülke (2012) reported that professional forecasters applied the Phillips curve when forecasting macroeconomic variables.
} 
Economic Research. ESP Forecast is a monthly survey on the macroeconomic outlook of Japan's economy including real GDP growth rate, core CPI inflation rate, yen-dollar exchange rate, and NY WTI crude oil futures price. Around 40 leading professional forecasters from private institutes in Japan participate in this survey. Estimating the panel Phillips curves for alternative periods, we derive how anchor of inflation expectations changed over time in Japan.

We find significant structural changes in how to form private inflation expectations. Before the BOJ announced the $2 \%$ inflation target, the estimated anchor of private inflation expectations was negative. But after the announcement, the new target increased the estimated anchor of inflation expectations significantly. This implies that the announcement of $2 \%$ target was successful in anchoring inflation expectations in positive values. However, the estimated anchor has never reached the target. More importantly it started to decline in 2015. It is likely that when it turned out that the $2 \%$ target would not be feasible in the short-run, Japanese forecasters came to place little weight on the $2 \%$ target in forming their inflation expectations. The result implies that an explicit inflation targeting regime can provide less uncertainty about future monetary policy actions only when it is a feasible target.

In literature, a number of studies used survey data of inflation expectations to examine whether the adoption of inflation targeting had helped to anchor inflation expectations. The results are mixed depending on whose inflation expectations were used in the analysis. Using survey data of firm managers and households, Kumar et al. (2015) found that the inflation expectations were not well anchored even in successful inflation targeting regime. In contrast, using survey data from Consensus Economics, Johnson (2002, 2003) showed that the expected inflation of professional forecasters was stabilized after the announcement of targets. Using the Consensus Economics data in Canada and the USA, Yetman (2017) found that an explicit inflation targeting regime provided for less uncertainty about future monetary policy actions to anchor expectations of professional forecasters. ${ }^{3}$

The results are also mixed on the effects of BOJ's dramatic policy changes. Using the QUICK survey system data for market participants, Fujiwara et al. (2015) found no sizable

\footnotetext{
${ }^{3}$ In addition to these studies, using Consensus Economics surveys, Levin et al. (2004) showed that for the industrialized economies, inflation target played a significant role in anchoring long-run inflation expectations. Using the data across 36 countries, Davis (2014) demonstrated that the inflation expectations of professional forecasters responded to an exogenous shock much less significantly in inflation targeting period.
} 
difference in perceptions of CPI inflations before and after the introduction of new monetary policy regime. Using an event-study approach, Bundick and Smith (2018) demonstrated that unlike in the USA, forward measures of nominal compensation in Japan continued to drift with news about current inflation even after the Bank of Japan adopted the inflation target. In contrast, Fukuda (2015) showed that financial market expectations changed dramatically after Prime Minister Abe had announced a new monetary policy regime in late 2012. Using survey data from Consensus Economics, Hattori and Yetman (2017) found that after the BOJ announced the $2 \%$ inflation target, the estimated anchors across forecasters have tended to rise, along with the dispersion in estimates across forecasters. Our results partly support the view that the BOJ's policy changes increased the anchored inflation expectations significantly. However, they also suggest that their effects were far from satisfactory in achieving the target.

In most advanced economies, inflation targeting had originally been introduced as a device to stabilize inflation at low levels. However, when inflation remained weak persistently, the central bank must bring inflation up to the target. Using survey data across 10 advanced economies from Consensus Economics, Ehrmann (2015) showed that inflation expectations of professional forecasters were not well anchored under persistently low inflation but that they were better anchored in inflation targeting countries. Our results are consistent with his results in that the BOJ's $2 \%$ target could raise inflation expectations towards significant positive values. However, we find that the effect did not persist when the BOJ's commitment turned out to be unfeasible. Inflation expectations are likely to be influenced not only by the central bank's target inflation rate but by the public's confidence in the central bank's achievement of the target rate. In Japan, a number of structural problems still underpin chronic low inflation (See, for example, Nishizaki et al. [2014] and Hasumi et al. [2018]). Thus unless solving these structural problems, an explicit inflation targeting could not anchor inflation expectations persistently. ${ }^{4}$

The paper proceeds as follows. Section 2 overviews how the BOJ's monetary policy and its targeted inflation rate changed and Section 3 explains the forecaster-level data of "ESP

\footnotetext{
${ }^{4}$ Mehrotra (2009) examined whether price level or inflation targeting would have been appropriate policy choices for Japan during its disinflation and deflation period. Yoshino and Miyamoto (2017) found that the effectiveness of fiscal and monetary policies was weakened when the proportion of retirees becomes larger. Hogen and Okuma (2018) explored why expectations had not been anchored at 2 percent in Japan since the late 1990s.
} 
Forecast”. Section 4 formulates an expectations-augmented Phillips curve and Section 5 discusses how to derive the anchor of inflation expectations by using the data of ESP Forecast. Section 6 shows the estimation results of our panel Phillips curves and Section 7 derives the anchor of inflation expectations. Sections 8 and 9 explore robustness of our estimation results. Section 10 summarizes our main results and refers to their implications.

\section{The BOJ's Unconventional Monetary Policy}

Before moving to the estimation, this section overviews how the BOJ's monetary policy and its targeted inflation rate changed after the Global Financial Crisis (GFC) in 2008. As summarized in Table 1, the BOJ adopted a series of unconventional monetary policies after the GFC. In particular, after the introduction of the "Quantitative and Qualitative Monetary Easing (QQE)” on April 4 in 2013, the BOJ became highly aggressive in its policy. It expanded the QQE on October 31 in 2014 and introduced two new frameworks, termed "QQE with a Negative Interest Rate," on January 29 in 2016 and “QQE with Yield Curve Control” on September 21 in 2016.

The BOJ also increased its targeted CPI inflation rate (the year-on-year rate of change in CPI) after the GFC. On December 18 in 2009, the BOJ clarified that the "medium- to long-term price stability" was around 1\% CPI inflation rate and declared that it would never tolerate the inflation rate equal to or below 0 percent. On February 14 in 2012, the BOJ suggested that it would set a goal at 1 percent for the time being. More importantly it announced introducing an explicit 2\% inflation target in the CPI on January 22 in 2013. Since the previous target was an implicit rate at around 1 percent, the announcement of the explicit $2 \%$ inflation target was a dramatic change in the BOJ's commitment. In particular, when introducing the QQE on April 4 in 2013, the BOJ made a commitment that it would achieve the CPI price stability target of 2 percent "at the earliest possible time, with a time horizon of about two years."

After announcing the $2 \%$ inflation target, the BOJ increased its estimates on future inflation rates substantially. Table 2 summarizes the BOJ's point estimates of after-tax core CPI inflation rate (CPI, all items less fresh food, excluding the direct effects of the consumption tax hikes) in each fiscal year after the GFC. In its Outlook for Economic Activity and Prices, 
the BOJ announces the point estimates of policy board members' forecasts four times a year: January, April, July, and October (or November). After $\mathrm{T}=2015$, the point estimate of the core CPI inflation rate in fiscal year $\mathrm{T}$ starts in April of year $\mathrm{T}-2$ and continues through to April in year $\mathrm{T}+1$, so that there are 12 forecasts for the same fixed event. Before $\mathrm{T}=2014$, the estimate starts in October of year $\mathrm{T}-2$ through to April in year $\mathrm{T}+1$, so that there are 10 forecasts for the same fixed event.

The table shows two interesting features. First the initial point estimate is in marked contrast before and after announcing the $2 \%$ inflation target. That is, the initial point estimate in October of year $\mathrm{T}-2$ was far below 1 percent before $\mathrm{T}=2014$, while the initial point estimate in April of year $\mathrm{T}-2$ was around 2 percent after $\mathrm{T}=2015$. This implies that the explicit 2\% inflation target increased the BOJ's initial point estimate of the CPI inflation rate dramatically. Second the accuracy of the initial point estimate declined substantially after announcing the $2 \%$ inflation target. Before $\mathrm{T}=2014$, the difference between the initial point estimate in October of year $\mathrm{T}-2$ and the final point estimate in April of year $\mathrm{T}+1$ was small and little biased: $0.4 \%$ points in $\mathrm{T}=2011,0.8 \%$ points in $\mathrm{T}=2012,0.3 \%$ points in $\mathrm{T}=2013$, and $0 \%$ points in $\mathrm{T}=2014$. In contrast, after $\mathrm{T}=2015$, the initial point estimate in April of year $\mathrm{T}-2$ overestimated the final point estimate substantially. The overestimation amounted to $1.9 \%$ points in $\mathrm{T}=2015,2.4 \%$ points in $\mathrm{T}=2016$, and $1.2 \%$ points in $\mathrm{T}=2017$. This implies that the explicit $2 \%$ inflation target reduced accuracy of the BOJ's initial estimate of the CPI inflation rate dramatically. The inaccuracy happened because despite the dramatic increases in the monetary base, the QQE could not achieve the price stability target of 2 percent (excluding the direct effects of the consumption tax hikes).

The inaccuracy also happened in the BOJ's projected timing of reaching around $2 \%$ inflation rate. Since April in 2015, the BOJ had delayed its projected timing frequently. Until October in 2014, its Outlook for Economic Activity and Prices stated that the projected timing would be "in or around fiscal 2015". But it delayed the timing to "around the first half of fiscal 2016” in April 2015, to "around the second half of fiscal 2016” in October 2015, to "around the first half of fiscal 2017" in January 2016, to "during fiscal 2017” in April 2016, to “around fiscal 2018” in November 2016, and to "around fiscal 2019” in July 2017. In April 2018, the BOJ eventually stopped announcing the projected timing in its statement. The frequent changes in the projected timing of reaching around 2 percent indicate that the $\mathrm{BOJ}$ is 
a central bank that has adopted an explicit inflation target but faced a serious difficulty in achieving the target.

\section{ESP Forecast}

The purpose of the following sections is to explore to what extent the BOJ's explicit inflation targeting regime could anchor inflation expectations by using "ESP Forecast". ESP (Economy, Society, Policy) Corporation started the survey in May 2004 and the Japan Center for Economic Research (JCER) succeeded it after April 2012. The monthly survey is conducted around the beginning of each month and its result is publicized in the middle of the month. In the sense that it sends questionnaires to professional economists, ESP Forecast is similar to Consensus Economics which has widely been used in literature. But the surveyed economists in ESP Forecast are more specialized in the Japanese economy than those in Consensus Forecast. The forecasted macroeconomic variables include growth rates of real GDP and its components, growth rate of industrial production index, current account, core CPI inflation rate (year-on-year), unemployment rate, Nikkei stock price index, the yen-dollar exchange rate, and NY WTI crude oil futures price.

The quoted forecasts are fixed event forecasts which consist of a panel of forecasts for a set of outturns of a series at varying horizons prior to each outturn. For most variables, when quoting forecasts of the value in fiscal year $\mathrm{T}$, the forecast origin starts in January of year $\mathrm{T}-1$ and continues through to May in year $\mathrm{T}+1$, so that there are 29 forecasts for the same fixed event. However, for real GDP growth rate and core CPI inflation rate, when quoting forecasts of the value in fiscal year $\mathrm{T}=2015,2016,2017$, and 2018, the forecast origin starts in June of year $\mathrm{T}-2$ and continues through to May in year $\mathrm{T}+1$. Thus for real GDP growth rate and core CPI inflation rate in fiscal year $\mathrm{T}$, there are 34 forecasts for the same fixed event after $\mathrm{T}=$ 2015.5

Fixed-event forecasts generally have a seasonal property where the number of forecast horizons is different depending on in which month the forecast is quoted. ESP Forecast also has a property that the number of the fixed events is different depending on in which month the forecast is quoted. The forecasted fixed event includes the values in fiscal years T- $1, \mathrm{~T}$,

5 Before $\mathrm{T}=2014$, the forecast origin started in January of year $\mathrm{T}-1$ even for real GDP growth rate and core CPI inflation rate. 
and $\mathrm{T}+1$ when the forecast origin is from January to May in year $\mathrm{T}$, while it includes the values in fiscal years $\mathrm{T}$ and $\mathrm{T}+1$ when the forecast origin is from June to December in year $\mathrm{T}$. In addition, after $\mathrm{T}=2013$, it also includes the value in fiscal year $\mathrm{T}+2$ for real GDP growth rate and core CPI inflation rate when the forecast origin is from June to December in year T.

Table 3 summarizes basic statistics of the forecasted real GDP growth rate and after-tax core CPI inflation rate from fiscal year 2010 to 2019. It reports average and standard deviation of the forecasted fiscal year T's values quoted in January in year T-1, July in year $\mathrm{T}-1$, January in year $\mathrm{T}$, July in year $\mathrm{T}$, and January in year $\mathrm{T}+1$. For both real GDP growth rate and core CPI inflation rate, the average forecasted value shows substantial variations between January in year $\mathrm{T}-1$ and January in year $\mathrm{T}+1$. But the standard deviation declines as the forecast origin approaches the forecasted year. This implies that the forecasters frequently revise their forecasts incorporating new information and eventually form almost homogeneous forecast. However, the standard deviations decline only modestly until July in year $\mathrm{T}$. This suggests that the fixed event forecasts remain heterogeneous until the realized values become available to the forecasters. Comparing the standard deviations between real GDP growth rate and core CPI inflation rate, the forecasted real GDP growth rates had been more heterogeneous than the forecasted core CPI inflation rate until $\mathrm{T}=2014$. However, after $\mathrm{T}=2015$, the forecasted core CPI inflation rate became more heterogeneous than the forecasted real GDP growth rates in January in year T-1 and July in year T-1. This suggests that the BOJ's dramatic policy changes reduced heterogeneity of medium-term GDP growth expectations but increased heterogeneity of medium-term inflation expectations.

\section{Basic Model}

In the following sections, we explore whether the BOJ's explicit inflation targeting regime could anchor inflation expectations through estimating Phillips curves in Japan. In the analysis, we use an expectations-augmented Phillips curve. Denoting the inflation rate by $\Pi_{t}$, GDP gap by $\ln Y_{t}-\ln Y_{t}^{*}$, and supply shocks by $U_{t}$, the Phillips curve is written as follows:

(1) $\Pi_{t}=\Pi_{t}^{e}+\alpha\left(\ln Y_{t}-\ln Y_{t}^{*}\right)+U_{t}$. 
where subscript $t$ denotes time period.

In the above equation, we denoted log linearized GDP gap by $\ln Y_{t}-\ln Y_{t}^{*}$ where $Y_{t}$ is real GDP and $Y_{t}^{*}$ is potential real GDP. The term $\Pi_{t}^{e}$ is the expected underlying inflation rate which is independent of GDP gap and supply shocks. It is different from average expected inflation rate because the expected effects of GDP gap and supply shocks are reflected in the expectations of $\alpha\left(\ln Y_{t}-\ln Y_{t}^{*}\right)$ and $U_{t}$ respectively. Since it has a feature of expected long-run inflation rate, we call $\Pi_{t}^{e}$ "the anchor of inflation expectations".

In the following analysis, we assume that forecasters form their inflation expectations by using equation (1). We also assume that when forecasting the macroeconomic values in time $t$, they form their expectations based on both public and private information available in time $t-1$. Then, defining the forecaster $j$ 's expectation operator based on information in time $t-1$ by $E_{j, t-1}$, we obtain

(2) $E_{j, t-1} \Pi_{t}=\Pi_{t}^{e}+\alpha \cdot E_{j, t-1}\left(\ln Y_{t}-\ln Y_{t}^{*}\right)+E_{j, t-1} U_{t}$.

In the above equation, it is worthwhile to note that there is no expectation operator $E_{j, t-1}$ for $\Pi_{t}^{e}$. This is because the anchor of inflation expectations is forecasted based only on public information in time $t-1$, so that it is common for all forecasters. We may interpret that superscript $e$ denotes the expectation operator based only on public information in time $t-1$.

We assume that potential real GDP grows at a constant rate in the short-run. Then because of no uncertainty in $\ln Y_{t}^{*}$, it holds that

(3) $E_{j, t-1}\left(\ln Y_{t}-\ln Y_{t}^{*}\right)=E_{j, t-1} \Delta \ln Y_{t}-\Delta \ln Y_{t}^{*}+\left(\ln Y_{t-1}-\ln Y_{t-1} *\right)$.

where $\Delta \ln Y_{t} \equiv \ln Y_{t}-\ln Y_{t-1}$ and $\Delta \ln Y_{t}^{*} \equiv \ln Y_{t}^{*}-\ln Y_{t-1} *$. Substituting equation (3) into equation (2), we obtain

(4) $E_{j, t-1} \Pi_{t}=\left[\Pi_{t}^{e}+\alpha\left\{\left(\ln Y_{t-1}-\ln Y_{t-1}^{*}\right)-\Delta \ln Y_{t}^{*}\right\}\right]+\left[\alpha \cdot E_{j, t-1} \Delta \ln Y_{t}+E_{j, t-1} U_{t}\right]$.

Equation (4) implies that forecaster $j$ 's inflation expectation formed in period $t-1$ consists of two components. One is $\left[\Pi_{t}{ }^{e}+\alpha\left\{\left(\ln Y_{t-1}-\ln Y^{*}\right)-\Delta \ln Y_{t}^{*}\right\}\right]$ which is common for all $j$. It is 
the sum of the anchor of inflation expectations and $\alpha \times$ [realized GDP gap in period $t-1-$ potential GDP growth rate]. The other is $\left[\alpha \cdot E_{j, t-1} \Delta \ln Y_{t}+E_{j, t-1} U_{t}\right]$ which is heterogeneous across the forecasters. It is the sum of the $\alpha \times$ forecaster $j$ 's GDP growth rate expectations and forecaster $j$ 's supply shock expectations. The following sections estimate equation (4) by forecaster-level data to derive the anchor of inflation expectations $\Pi_{t}^{e}$ in each period.

\section{The Estimation Equation}

In the following section, we derive the anchor of inflation expectations $\Pi_{t}^{e}$ by using the data of ESP Forecast. In the analysis, we assume that each professional forecaster applies equation (1) when forecasting macroeconomic variables in Japan. We then estimate the following cross-sectional equation:

(5) $E_{j, \tau} \Pi_{\tau+1}=$ constant term $+\alpha \cdot E_{j, \tau} \Delta \ln Y_{\tau+1}+\sum_{i=1}^{N} \beta_{i, t} E_{j, \tau} \Delta \ln X_{\tau}^{i}+\varepsilon_{j \tau}$,

where $E_{j, \tau} \Pi_{\tau+1}=j$ 's inflation forecast, $E_{j, \tau} \Delta \ln Y_{\tau+1}=j$ 's real GDP growth rate forecast, and $E_{j, \tau} \Delta \ln X_{\tau}^{i}=j$ 's forecast of supply shocks. The expectation operator $E_{j, \tau}$ suggests that forecaster $j$ forms his or her expectation in period $\tau$ to forecast the value in period $\tau+1$.

Equation (5) is the ESP Forecast version of equation (4), where the constant term is the sum of the anchor of inflation expectations and $\alpha$ [realized GDP gap in period $t-1$ - potential GDP growth rate]. ${ }^{6}$ In ESP Forecast, we can observe both $E_{j, \tau} \Pi_{\tau+1}$ and $E_{j, \tau} \Delta \ln Y_{\tau+1}$ for several alternative horizons. However, we cannot observe $E_{j, \tau} \Delta \ln X_{\tau}^{i}$ directly. We thus use $j$ 's forecasts of the yen-dollar exchange rate and the NY WTI crude oil futures price for proxies of supply shocks. Since only the forecasted level is available for these variables in ESP Forecast, we constructed their changes by taking logged difference between the forecasted future value and the realized current value.

When estimating equation (5), we use inflation forecasts of after-tax core CPI for $E_{j, \tau} \Pi_{\tau+1}$. The sample period of the forecast origin is from June 2011 to March 2018. We start the sample period from June 2011 to exclude discontinuous changes in ESP Forecast caused by

${ }^{6}$ The constant term can change over time when $\tau$ changes. But to the extent that $\tau$ is fixed, it is time invariant in each estimated estimation. 
the CPI base year revision. The sample period allows us to see whether there were structural changes in equation (5) after the BOJ introduced the explicit 2\% inflation target in January 2013.

As we explained in section 3, ESP Forecast provides a panel of the fixed event forecasts at various horizons. It is, however, worthwhile to note that the quoted forecast monotonically diverges from the long-run anchor point and converges towards actual value as the forecast horizon shortens. In particular, when the value in fiscal year $\mathrm{T}$ is forecasted from January to May in year $\mathrm{T}+1$, most of their components have already been realized. Even when the value in fiscal years $\mathrm{T}$ is forecasted from June to December in year $\mathrm{T}$, some of their components have already been realized. Thus in the analysis, we exclude these forecasts and focus only on the following four types of forecasts.

The first type (type I) is a set of forecasted values in fiscal year $\mathrm{T}+2$ which are quoted from June to December in year T. They have a desirable property to see anchor of medium-term inflation forecasts in that their forecast horizons are the longest in ESP Forecast. But available forecasted variables are limited to real GDP growth rate and core CPI inflation rate. Thus when calculating the anchor, we cannot remove the effects of supply shocks in the first type.

The second type (type II) is a set of forecasted values in fiscal year $\mathrm{T}+1$ which are quoted from January to May in year T. Their forecast horizons are slightly shorter than those in the first type but longer than the other two types. More importantly the second type includes forecasted values of various macro variables, especially the yen-dollar exchange rate and the oil price. Thus we can calculate the anchor of medium-term inflation forecasts after controlling for the effects of supply shocks in the second type.

The third type (type III) is a set of forecasted values in fiscal year $\mathrm{T}+1$ which are quoted from June to December in year T. Since the third type also includes forecasted values of various macro variables, we can derive the anchor after controlling for the effects of supply shocks. But since their forecast horizons are shorter, the anchor is likely to be that of short-term inflation forecasts.

The fourth type (type IV) is a set of forecasted values in fiscal year T which are quoted from January to May in year T. It also includes forecasted values of various macro variables. Since the forecast horizons are the shortest, forecast errors tend to be the smallest among the four types. We may interpret that the forecast values reflect short-term expectations. They are 
likely to have very different features from long-term expectations.

\section{The Estimation Results}

We estimated equation (5) by using panel data of the four alternative types of forecasts. Table 4 reports the estimation results with and without supply shocks for each type of forecasts. The estimations were implemented either with or without monthly time dummies.

The estimated coefficient of the GDP growth rate forecast was positive in all cases and statistically significant except for type I forecasts in 2014. This implies that ESP Forecast supports our Phillips curve. However, the estimated coefficient tended to be larger when the forecast origin was in the QQE period than when it was in the pre-QQE period. That is, in the pre-QQE period, the estimated coefficient was less than 0.2 in most cases and rarely exceeded 0.3, which implies that the Phillips curve was very flat. In contrast, in the QQE period, the estimated coefficient frequently exceeded 0.4 and rarely fell below 0.2. In particular, it exceeded 0.7 for type II forecasts in 2018. This indicates that the BOJ's unprecedented monetary easing made the inflation forecast more sensitive to the GDP growth forecast and made the slope of our panel Phillips curve steeper.

More importantly, the estimated constant term also changed over time. In the table, the estimated constant term had three features depending on when the forecast origin was. First it was negative in most cases when the forecast origin was before announcing the $2 \%$ inflation target. When the forecast origin was in 2011 or 2012, the estimated constant term was always less than -0.15. The negative value was particularly substantial in short-term forecasts (that is, type III and IV forecasts) where it sometimes fell below -0.5. Second it became significantly positive and sometimes took large positive values when the forecast origin was soon after announcing the 2\% inflation target. Except for type IV forecasts, the estimated constant term was always positive when the forecast origin was after 2013. In particular, it became large from June 2013 to December 2014 for type III and IV forecasts and from June 2014 to May 2016 for type I and II forecasts. Third it started to decline when the forecast origin was after 2015. For type III and IV forecasts, the estimated constant term sometimes became less significant after 2015. For type I and II forecasts, the estimated constant term always remained statistically significant even after 2015. But its absolute value declined after June 
2016.

The above results suggest that the intercept of our panel Philipps curve, which was negative before announcing the $2 \%$ target, increased substantially soon after announcing the $2 \%$ target. In other words, the Phillips curve shifted upward soon after announcing the $2 \%$ target. The BOJ's explicit inflation target could partly anchor inflation expectations. However, the intercept of our panel Philipps curve declined significantly as the QQE progressed. The upward shift did not persist when it turned out that the $2 \%$ target would not be feasible in the short-run. This implies that an explicit inflation targeting needs to be a feasible one to shift the Phillips curve upward persistently.

Comparing the results with and without supply shocks, the estimated constant term without supply shocks was always greater than that with supply shocks. This implies that yen's depreciation and oil price increases were one of the reasons why our Phillips curve shifted upward in the QQE period. However, even if we control for the effects of these supply shocks, we can still observe that the constant term increased soon after announcing the $2 \%$ inflation target but declined as the QQE progressed. The upward and downward shifts of the Phillips curve occurred even if we controlled the effects of the supply shocks.

Among the four types of forecasts, the constant term for types I and II forecasts tended to be higher than that for the other two types in the QQE period. In particular, it remained higher even if the QQE progressed. The estimated constant term exceeded 1.0 for type I forecasts when the forecast origin was in 2015 and 2016 and 0.8 for type II forecasts when the forecast origin was in 2016. It was only after 2017 when the estimated constant term started to decline. In contrast, the constant term for types III and IV forecasts not only showed modest increases in the QQE period but also started to decline earlier as the QQE progressed. As explained in the last section, forecasts for types I and II forecasts are those with longer time horizons, while forecasts for types III and IV forecasts are those with shorter time horizons. It is likely imply that depending on the length of forecast time horizons, the shifts in the Phillips curve were different in their magnitude and timing.

\section{The Estimated Anchor of the Inflation Expectation}

One of the key features in our expectations-augmented Phillips curve is that the constant 
term equals to the sum of $\Pi_{\tau}^{e}$ and $\alpha$ [GDP gap in period $\tau$ - potential GDP growth rate], where $\tau$ is the period of the forecast origin. This indicates that we can derive the estimated anchor of inflation expectations subtracting $\widehat{\alpha}$ [GDP gap in period $\tau$ - potential GDP growth rate] from the estimated constant term, where $\widehat{\alpha}$ is the estimated coefficient of the GDP growth rate forecast.

In deriving the anchor of inflation expectations, we used the potential GDP growth rate and GDP gap both of which were estimated by Cabinet Office of Japanese government (September 2018 version). Since no estimated potential growth rate was available in 2018 and 2019, we set potential GDP growth rate in 2018 and 2019 to be 1.0 percent which equals to the estimated rate in 2015 and 2016. For GDP gap, we first took average of the quarterly series from the third quarter in 2013 to the fourth quarter in 2014 to smooth out the effect of consumption tax hikes. We then converted the smoothed quarterly series into semi-annual series through taking their moving averages. ${ }^{7}$ Based on the estimated results without monthly time dummies in Table 4, Figure 2 depicts how the derived anchor of inflation expectations changed over time for the four types of forecasts. The figure has three noteworthy features.

First, when the forecast origin was in 2011 and 2012, the derived anchor was negative for types III and IV forecasts and was close to zero for type II forecasts. This implies that inflation expectations had been anchored in non-positive values before the BOJ announced 2\% target in January 2013. After the GFC, the CPI inflation rates had been negative in Japan in most of the periods until May 2013. It is likely that the persistent CPI declines occurred not only because recessions had been prolonged but also because non-positive inflation expectations had been anchored persistently.

Second, the derived anchor increased significantly in 2013 and in 2014 and remained positive in the following years. This implies that the announcement of $2 \%$ target was successful in anchoring inflation expectations in positive values. Since the previous targeted rate was around 1 percent, the announcement of the $2 \%$ target was a dramatic change in the BOJ's commitment. In particular, when introducing the QQE on April 4, 2013, the BOJ made a commitment that it would achieve the CPI price stability target of 2 percent "at the earliest possible time.” It is likely that the dramatic change in the BOJ's policy regime was successful

7 Specifically, we calculated the semi-annual series for types I and II by [(2nd quarter gap) + $3 *$ (3rd quarter gap) $+3 *(4$ th quarter gap) $] / 7$ and the semi-annual series for types II and IV by $[3 *(1$ st quarter gap $)+2 *(2$ nd quarter gap $)] / 5$. 
in shifting anchor of inflation expectations upward.

Third, despite the upward shift after the announcement of $2 \%$ target, the derived anchor never reached 2 percent. It never exceeded 1.5\% when we controlled the effects of supply shocks. It exceeded 1.5\% in 2015 for type I forecasts and in 2016 for type II forecasts when we did not control the effects of supply shocks. But even in these cases, the increased anchor did not persist. This implies that the announcement of $2 \%$ target was not successful in anchoring inflation expectations at the targeted rate. After introducing the QQE, the CPI inflation rate turned into positive in Japan. However, it started to decline in the latter half of 2014. It is likely that the role of the explicit inflation target faced structural changes in anchoring inflation expectations in Japan when it turned out that the $2 \%$ target would not be feasible in the short-run.

Comparing the four types of forecasts, the derived anchors in types III and IV not only increased earlier after the $2 \%$ target announcement but also started to decline earlier as the QQE progressed. This implies that the short-term anchor of inflation expectations were more sensitive not only to the $2 \%$ target announcement but also to the following inflation decline. In contrast, the derived anchors in type I and II forecasts started to increase in larger scale after the anchors in type III and IV forecasts had already increased. The medium-term anchor of inflation expectations showed delayed but larger fluctuations than the short-term anchor after the $2 \%$ target announcement. However, even in the medium-term forecasts, the increases in the anchor of inflation expectations did not persist when it turned out that the $2 \%$ target would not be feasible in the short-run.

\section{Robustness I: Instrumental variables}

In previous sections, we derived the anchor of inflation expectations through estimating equation (5) by ordinary least squares. But the use of ordinary least squares raises concern about possible simultaneous biases in the estimation. The purpose of this section is to examine whether our results are robust even when estimating equation (5) by instrumental variable method. Specifically, we estimate equation (5) by using one-month lagged values of the GDP growth rate forecasts, the yen-dollar exchange forecasts, and the crude oil futures 
price forecasts as instrumental variables to derive anchor of inflation expectations. ${ }^{8}$ One problem for using the instrumental variables is that no appropriate lagged value is available when the forecast origin is in January for type II or IV forecasts and in July for type I or III forecasts. This happens because ESP Forecast is a fixed-event forecast where the forecast horizons are different depending on in which month the forecast is quoted. Thus, when using the instrumental variable method, we estimate equation (5) using panel data from February to June for type II and IV forecasts and from August to December for type I and III forecasts.

Table 5 reports the estimation results with and without supply shocks for the four alternative types of forecasts. As in the previous sections, the estimations were implemented either with or without monthly time dummies. Because of limited availability of instrumental variables, the number of observations became smaller. Compared with those in Table 4, the constant term became insignificant in 2012 for type II forecasts and in 2018 for type IV forecasts. However, most of the estimated coefficients remained statistically significant and were essentially the same as those in table 4 even if we estimated by using the instrumental variables.

The estimated coefficient of the GDP growth rate forecast was positive in all cases but became larger in the QQE period than in the pre-QQE period. More importantly, the estimated constant term which had been negative in most cases, became significantly positive after announcing the $2 \%$ target and then started to decline around 2015. This indicates that the BOJ's unprecedented monetary easing shifted our panel Phillips curve upward for a few years but that the upward shift did not persist when it turned out that the $2 \%$ target would not be feasible in the short-run.

Based on the estimated results without monthly time dummies in Table 5, we derived the anchor of inflation expectations $\Pi_{\tau}^{e}$ for the four types of forecasts using the same method in section 7. Figure 3 depicts how the derived anchors of inflation expectations changed over time. Although some slight differences exist, they are essentially the same as those in Figure 2. That is, the derived anchor, which tended to be negative before announcing the $2 \%$ target, increased significantly in 2013 and in 2014 and remained positive in the following years. However, despite the upward shift, the derived anchor never reached 2 percent. This implies

8 In case of type I forecasts, we use one-month lagged values of the GDP growth rate forecasts as an instrumental variable because the yen-dollar exchange forecasts and the crude oil futures price forecasts are not available. 
that the announcement of $2 \%$ target was successful in anchoring inflation expectations in positive values but was not successful in anchoring them at the targeted rate.

\section{Robustness II: Additional exogenous shocks}

Until the last section, we have derived the anchor of inflation expectations using forecasts of the yen-dollar exchange rate and the NY WTI crude oil futures price as supply shocks. We used them because both foreign exchange rates and oil prices have been major sources of supply shocks in the Japanese economy. However, in integrated global production networks, the Japanese economy is increasingly more connected with the rest of the world, especially with the USA and China. The purpose of this section is to examine whether our results are robust even if we estimate equation (5) including forecasted growth rates of the USA and China as additional exogenous shocks. In the estimation, we take the difference between the forecasted and the realized values of the US and China's growth rates respectively to calculate the additional exogenous shocks.

Putting aside including two additional explanatory variables, the estimated equation is the same as those in Table 3. Table 6 reports the estimation results with and without monthly time dummies for types II, III, and IV of forecasts. The additional shocks frequently took significantly positive sign. This implies that accelerated growth in the USA and China had positive spillover effects on the inflation rate in Japan. Compared with those in Table 3, the constant term became insignificant in 2014 for type II forecasts, in 2016 for type III forecasts, and in 2017 for type IV forecasts. However, most of the estimated coefficients remained statistically significant and were essentially the same as those in table 4.

The estimated coefficient of the GDP growth rate forecast was significantly positive in all cases but became larger in the QQE period than in the pre-QQE period. More importantly, the estimated constant term changed over time. It was negative in most cases before announcing the $2 \%$ target. However, it became significantly positive after announcing the $2 \%$ target and then started to decline around 2016.

Based on the estimated results without monthly time dummies in Table 6, we derived the anchor of inflation expectations for the four types of forecasts using the same method in section 7. Figure 4 depicts how the derived anchors of inflation expectations changed over 
time when excluding the effects of the supply shocks and the two exogenous shocks. Compared with those in Figure 2, the derived anchors in the figure were slightly larger and for type II forecasts and slightly smaller for type III and IV forecasts. However, their features are essentially the same as those in Figure 2. The announcement of $2 \%$ target was successful in anchoring inflation expectations in positive values but was not successful in anchoring them at the targeted rate.

\section{Concluding Remarks}

In this paper, we explored whether the explicit inflation targeting regime could anchor inflation expectations in Japan. In the analysis, we estimated panel Phillips curves by using Japanese forecaster-level data of "ESP Forecast". We found significant structural changes in how to form private inflation forecasts. Before the BOJ announced the $2 \%$ target, inflation expectations had been anchored in negative values, which caused prolonged deflation after the GFC. But the new target increased anchor of inflation expectations to significant positive values. This implies that the $2 \%$ target was successful in overcoming prolonged deflation. However, the estimated anchor has never reached the target. This implies that an explicit inflation target was far from satisfactory to anchor inflation expectations in desirable values.

The Japanese economy is an exceptional country that has been suffering from extremely low inflation since the mid-1990s. To overcome prolonged deflationary mindset, the BOJ announced the 2\% inflation target in January 2013 and made a commitment that it would achieve the target "with a time horizon of about two years" in April 2013. But despite the unprecedented monetary easing, the BOJ kept facing a serious difficulty in achieving the target. Fujiki and Tomura (2018) discussed possible scenarios after the BOJ achieves the inflation target. Our empirical results, however, suggest that it is still a long way for the BOJ to anchor inflation expectations in desirable values.

\section{References}

Beechey, M. J., B. K. Johannsen, and A. T. Levin, (2011), "Are long-run inflation expectations anchored more firmly in the Euro area than in the United States?" American 
Economic Journal: Macroeconomics, 3(2), pp.104-129.

Bernanke, B. S., T. Laubach, F. S. Mishkin, and A. S. Posen, (1999), Inflation Targeting: Lessons from the International Experience, Princeton University Press, Princeton, NJ.

Bundick, Brent, and A. Lee Smith, (2018), “Does communicating a numerical inflation target anchor inflation expectations? Evidence \& bond market implications.” Federal Reserve Bank of Kansas City, Research Working Paper no. 18-01, January.

Davis, S., (2014), "Inflation targeting and the anchoring of inflation expectations: Cross-country evidence from consensus forecasts." Globalization and Monetary Policy Institute Working Paper 174, Federal Reserve Bank of Dallas.

Ehrmann, M., (2015), "Targeting inflation from below: How do inflation expectations behave," International Journal of Central Banking, 11(S1), pp.213-249.

Fukuda, S., (2015), "Abenomics: Why was it so successful in changing market expectations?" Journal of the Japanese and International Economies, Volume 37, pp.1-20.

Fujiki, H., and H. Tomura, (2018), "Fiscal cost to exit quantitative easing: the case of Japan," Japan and the World Economy, Volume 42, pp.1-11.

Fujiwara, I., Y. Nakazono, and K. Ueda, (2015), "Policy regime change against chronic deflation? Policy option under a long-term liquidity trap," Journal of the Japanese and International Economies, Volume 37, pp.59-81.

Gürkaynak R. S., A. T. Levin, and E. T. Swanson, (2010), "Does inflation targeting anchor long-run inflation expectations? Evidence from long-term bond yields in the U.S., U.K., and Sweden." Journal of the European Economic Association, 8(6), pp.1208-1242.

Hasumi, R., H. Iiboshi, and D. Nakamura, (2018), "Trends, cycles and lost decades: Decomposition from a DSGE model with endogenous growth," Japan and the World Economy, Volume 46, pp.9-28.

Hattori, M., and J. Yetman, (2017), "The evolution of inflation expectations in Japan," Journal of the Japanese and International Economies, Volume 46, Pages pp.53-68.

Hogen, Y., and R. Okuma, (2018), "The anchoring of inflation expectations in Japan: A learning-approach perspective," Bank of Japan Working Paper Series 18-E-8.

Johnson, D. R., (2002), "The effect of inflation targeting on the behavior of expected inflation: Evidence from an 11 country panel,” Journal of Monetary Economics 49 (8): pp.1521-38. Johnson, D. R., (2003), "The effect of inflation targets on the level of expected inflation in 
five countries," Review of Economics and Statistics 85 (4): pp.1076-81.

Kumar, S., H. Afrouzi, O. Coibion, and Y. Gorodnichenko, (2015), "Inflation targeting does not anchor inflation expectations: Evidence from firms in New Zealand.” Brookings Papers on Economic Activity, Fall, pp.151- 225.

Levin, A. T., F. M. Natalucci, and J. M. Piger, (2004), "The macroeconomic effects of inflation targeting." Federal Reserve Bank of St. Louis Review, 86(4), pp.51-80.

Mehrotra, A., (2009), "The case for price level or inflation targeting-What happened to monetary policy effectiveness during the Japanese disinflation?" Japan and the World Economy, Volume 21, Issue 3, pp.280-291.

Nishizaki, K., T. Sekine, and Y. Ueno (2014) "Chronic deflation in Japan." Asian Economic Policy Review, 9(1), pp.20-39.

Rülke, J.-C., (2012), "Do professional forecasters apply the Phillips curve and Okun's law? Evidence from six Asian-Pacific countries," Japan and the World Economy, Volume 24, Issue 4, pp.317-324.

Yetman, J., (2017), "The evolution of inflation expectations in Canada and the US," Canadian Journal of Economics, vol. 50(3), pp.711-737.

Yoshino, N., and H. Miyamoto, (2017), "Declined effectiveness of fiscal and monetary policies faced with aging population in Japan," Japan and the World Economy, Volume 42, pp.32-44 
Table 1. Timeline of Japan's Unconventional Monetary Policy

\begin{tabular}{|l|l|l|l|}
\hline Date & Description & Governor \\
\hline 19-Dec-08 & $\begin{array}{l}\text { Lowering of the Bank's target for the uncollateralized overnight call rate } \\
\text { by 20 basis points; it will be encouraged to remain at around 0.1 percent. } \\
\text { 18-Dec-09 }\end{array}$ & $\begin{array}{l}\text { The midpoints of most Policy Board members' "understanding" are around } \\
1 \text { percent CPI inflation rate. }\end{array}$ & Shirakawa \\
\hline 5-Oct-10 & $\begin{array}{l}\text { Comprehensive Monetary Easing } \\
\text { The "2\% Price Stability Target" under the Framework for the Conduct of } \\
\text { 22-Jan-13 }\end{array}$ & Shirakawa \\
\hline Monetary Policy & Shirakawa \\
\hline 31-Apr-13 & $\begin{array}{l}\text { Introduction of the "Quantitative and Qualitative Monetary } \\
\text { Easing (QQE)" }\end{array}$ & QQE1 & Kuroda \\
\hline 29-Jan-16 & $\begin{array}{l}\text { Expansion of the Quantitative and Qualitative Monetary Easing } \\
\text { with a Negative Interest Rate" }\end{array}$ & QQE2 & Kuroda \\
\hline 21-Sep-16 & $\begin{array}{l}\text { New Framework for Strengthening Monetary Easing: } \\
\text { "Quantitative and Qualitative Monetary Easing with Yield Curve } \\
\text { Control" }\end{array}$ & NIRP2 & Kuroda \\
\hline
\end{tabular}

Source: The Bank of Japan. 
Table 2. The BOJ's Point Estimates of Core CPI Inflation Rates

\begin{tabular}{|c|c|c|c|c|c|c|c|c|c|c|}
\hline \multirow{2}{*}{$\begin{array}{l}\text { forecast } \\
\text { origin }\end{array}$} & \multicolumn{10}{|c|}{ Estimated fiscal year $T$} \\
\hline & FY2011 & FY2012 & FY2013 & FY2014 & FY2015 & FY2016 & FY2017 & FY2018 & FY2019 & FY2020 \\
\hline April in T-2 & NA & NA & NA & NA & 1.9 & 2.1 & 1.9 & 1.9 & 1.9 & 1.8 \\
\hline July in $\mathrm{T}-2$ & NA & NA & NA & NA & 1.9 & 2.1 & 1.8 & 1.9 & 1.8 & 1.6 \\
\hline Oct. in T-2 & -0.4 & 0.6 & 0.5 & 0.8 & 1.9 & 2.1 & 1.8 & 1.7 & 1.8 & 1.5 \\
\hline Jan. in T-1 & -0.2 & 0.6 & 0.5 & 0.9 & 1.9 & 2.2 & 1.8 & 1.7 & 1.8 & NA \\
\hline April in T-1 & 0.1 & 0.7 & 0.7 & 1.4 & 1.9 & 2 & 1.7 & 1.7 & 1.8 & NA \\
\hline July in T-1 & 0.1 & 0.7 & 0.7 & 1.3 & 1.9 & 1.9 & 1.7 & 1.5 & 1.5 & NA \\
\hline Oct. in $\mathrm{T}-1$ & 0.1 & 0.1 & 0.4 & 1.3 & 1.7 & 1.4 & 1.5 & 1.4 & 1.4 & NA \\
\hline Jan. in T & 0.3 & 0.1 & 0.4 & 1.3 & 1 & 0.8 & 1.5 & 1.4 & NA & NA \\
\hline April in $\mathrm{T}$ & 0.7 & 0.3 & 0.7 & 1.3 & 0.8 & 0.5 & 1.4 & 1.3 & NA & NA \\
\hline July in $\mathrm{T}$ & 0.7 & 0.2 & 0.6 & 1.3 & 0.7 & 0.1 & 1.1 & 1.1 & NA & NA \\
\hline Oct. in $\mathrm{T}$ & 0 & -0.1 & 0.7 & 1.2 & 0.1 & -0.1 & 0.8 & 0.9 & NA & NA \\
\hline Jan. in $T+1$ & -0.1 & -0.2 & 0.7 & 0.9 & 0.1 & -0.2 & 0.8 & NA & NA & NA \\
\hline April in $T+1$ & 0 & -0.2 & 0.8 & 0.8 & 0 & -0.3 & 0.7 & NA & NA & NA \\
\hline realized rate & 0 & -0.2 & 0.8 & 0.8 & 0 & -0.2 & 0.7 & NA & INA & NA \\
\hline
\end{tabular}

Source: Outlook for Economic Activity and Prices, the Bank of Japan. 
Table 3. The Basic Statistics of Forecasted Values

(1) Real GDP growth rate

\begin{tabular}{|c|c|c|c|c|c|c|}
\hline & & Jan. in T-1 & July in $T-1$ & Jan. in T & July in $\mathrm{T}$ & Jan. in $T+1$ \\
\hline \multirow[t]{2}{*}{ FY2010 } & average & 1.21 & 1.11 & 1.25 & 2.47 & 3.22 \\
\hline & standard deviation & 0.52 & 0.61 & 0.39 & 0.33 & 0.18 \\
\hline \multirow[t]{2}{*}{ FY2011 } & average & 1.65 & 1.81 & 1.39 & 0.17 & -0.33 \\
\hline & standard deviation & 0.38 & 0.43 & 0.33 & 0.40 & 0.27 \\
\hline \multirow[t]{2}{*}{ FY2012 } & average & 2.06 & 2.92 & 1.89 & 2.32 & 0.99 \\
\hline & standard deviation & 0.30 & 0.35 & 0.43 & 0.22 & 0.15 \\
\hline \multirow[t]{2}{*}{ FY2013 } & average & 1.42 & 1.59 & 1.61 & 2.75 & 2.53 \\
\hline & standard deviation & 0.51 & 0.39 & 0.43 & 0.25 & 0.12 \\
\hline \multirow[t]{2}{*}{ FY2014 } & average & 0.23 & 0.58 & 0.84 & 0.85 & -0.60 \\
\hline & standard deviation & 0.56 & 0.48 & 0.35 & 0.31 & 0.15 \\
\hline \multirow[t]{2}{*}{ FY2015 } & average & 1.35 & 1.35 & 1.75 & 1.66 & 1.05 \\
\hline & standard deviation & 0.32 & 0.28 & 0.36 & 0.24 & 0.11 \\
\hline \multirow[t]{2}{*}{ FY2016 } & average & 1.63 & 1.73 & 1.44 & 0.62 & 1.21 \\
\hline & standard deviation & 0.38 & 0.30 & 0.26 & 0.26 & 0.10 \\
\hline \multirow[t]{2}{*}{ FY2017 } & average & 0.06 & 0.84 & 1.12 & 1.40 & 1.88 \\
\hline & standard deviation & 0.31 & 0.30 & 0.24 & 0.16 & 0.11 \\
\hline \multirow[t]{2}{*}{ FY2018 } & average & 1.02 & 1.10 & 1.26 & NA & NA \\
\hline & standard deviation & 0.36 & 0.28 & 0.22 & NA & NA \\
\hline \multirow[t]{2}{*}{ FY2019 } & average & 0.77 & NA & NA & NA & NA \\
\hline & standard deviation & 0.25 & NA & NA & NA & NA \\
\hline
\end{tabular}

(2) Core CPI inflation rate

\begin{tabular}{|c|c|c|c|c|c|c|}
\hline & & Jan. in T-1 & July in $\mathrm{T}-1$ & Jan. in T & July in T & Jan. in $T+1$ \\
\hline \multirow[t]{2}{*}{ FY2010 } & average & 0.19 & -0.51 & -0.93 & -0.92 & -0.85 \\
\hline & standard deviation & 0.41 & 0.43 & 0.32 & 0.18 & 0.08 \\
\hline \multirow[t]{2}{*}{ FY2011 } & average & -0.31 & -0.05 & -0.18 & 0.50 & -0.10 \\
\hline & standard deviation & 0.32 & 0.20 & 0.19 & 0.22 & 0.09 \\
\hline \multirow[t]{2}{*}{ FY2012 } & average & 0.14 & 0.33 & -0.20 & 0.06 & -0.15 \\
\hline & standard deviation & 0.27 & 0.29 & 0.26 & 0.14 & 0.07 \\
\hline \multirow[t]{2}{*}{ FY2013 } & average & 0.14 & 0.20 & 0.10 & 0.36 & 0.72 \\
\hline & standard deviation & 0.26 & 0.21 & 0.25 & 0.14 & 0.09 \\
\hline \multirow[t]{2}{*}{ FY2014 } & average & 2.34 & 2.71 & 0.88 & 1.12 & 0.95 \\
\hline & standard deviation & 0.38 & 0.32 & 0.30 & 0.17 & 0.08 \\
\hline \multirow[t]{2}{*}{ FY2015 } & average & 0.97 & 1.79 & 0.84 & 0.33 & 0.11 \\
\hline & standard deviation & 0.41 & 0.38 & 0.33 & 0.22 & 0.07 \\
\hline \multirow[t]{2}{*}{ FY2016 } & average & 1.27 & 1.22 & 0.82 & 0.03 & -0.25 \\
\hline & standard deviation & 0.48 & 0.41 & 0.33 & 0.24 & 0.06 \\
\hline \multirow[t]{2}{*}{ FY2017 } & average & 1.13 & 0.72 & 0.77 & 0.70 & 0.66 \\
\hline & standard deviation & 0.35 & 0.42 & 0.24 & 0.15 & 0.08 \\
\hline \multirow[t]{2}{*}{ FY2018 } & average & 0.99 & 0.89 & 0.88 & NA & NA \\
\hline & standard deviation & 0.35 & 0.31 & 0.28 & NA & NA \\
\hline \multirow[t]{2}{*}{ FY2019 } & average & 0.90 & NA & NA & NA & NA \\
\hline & standard deviation & 0.40 & NA & NA & NA & NA \\
\hline
\end{tabular}


Table 4. Basic Estimation Results

(1-a). Without supply shocks: Type I

\begin{tabular}{|c|c|c|c|c|c|}
\hline & $\begin{array}{l}\text { Constant } \\
\text { term } \\
\end{array}$ & $\begin{array}{l}\text { Real GDP } \\
\text { growth } \\
\end{array}$ & \# of obs. & R-squared & $\begin{array}{l}\text { Horizon } \\
\text { dummies }\end{array}$ \\
\hline \multirow[t]{4}{*}{2013 06-12 } & $0.287 * * *$ & $0.527 * * *$ & 289 & 0.253 & $\mathrm{NO}$ \\
\hline & $(0.0638)$ & $(0.0523)$ & & & \\
\hline & $0.287 * * *$ & $0.527 * * *$ & 289 & 0.257 & YES \\
\hline & $(0.0646)$ & $(0.0529)$ & & & \\
\hline \multirow[t]{4}{*}{2014 06-12 } & $1.094 * * *$ & 0.164 & 289 & 0.019 & $\mathrm{NO}$ \\
\hline & (0.151) & $(0.110)$ & & & \\
\hline & $1.103^{* * *}$ & 0.157 & 289 & 0.020 & YES \\
\hline & $(0.165)$ & $(0.120)$ & & & \\
\hline \multirow[t]{4}{*}{2015 06-12 } & $1.227 * * *$ & $0.205^{* * *}$ & 268 & 0.044 & $\mathrm{NO}$ \\
\hline & $(0.0253)$ & $(0.0755)$ & & & \\
\hline & $1.229 * * *$ & $0.199 * *$ & 268 & 0.054 & YES \\
\hline & $(0.0259)$ & $(0.0767)$ & & & \\
\hline \multirow[t]{4}{*}{2016 06-12 } & $0.344^{* * *}$ & $0.644^{* * *}$ & 285 & 0.452 & $\mathrm{NO}$ \\
\hline & $(0.0429)$ & $(0.0413)$ & & & \\
\hline & $0.344^{* * *}$ & $0.643^{* * *}$ & 285 & 0.455 & YES \\
\hline & $(0.0437)$ & $(0.0421)$ & & & \\
\hline \multirow[t]{4}{*}{$201706-12$} & $0.678 * * *$ & $0.450 * * *$ & 263 & 0.093 & $\mathrm{NO}$ \\
\hline & $(0.0843)$ & $(0.110)$ & & & \\
\hline & $0.675^{* * *}$ & $0.455^{* * *}$ & 263 & 0.100 & YES \\
\hline & $(0.0844)$ & $(0.111)$ & & & \\
\hline
\end{tabular}


Table 4. Basic Estimation Results (continued)

(1-b). Without supply shocks: Type II

\begin{tabular}{|c|c|c|c|c|c|}
\hline & $\begin{array}{l}\text { Constant } \\
\text { term }\end{array}$ & $\begin{array}{l}\text { Real GDP } \\
\text { growth }\end{array}$ & \# of obs. & R-squared & $\begin{array}{l}\text { Horizon } \\
\text { dummies }\end{array}$ \\
\hline \multirow[t]{4}{*}{2012 01-05 } & $-0.239 * * *$ & $0.250 * * *$ & 210 & 0.164 & $\mathrm{NO}$ \\
\hline & $(0.0796)$ & (0.0549) & & & \\
\hline & $-0.245^{* * *}$ & $0.253^{* * *}$ & 210 & 0.188 & YES \\
\hline & $(0.0791)$ & $(0.0547)$ & & & \\
\hline \multirow[t]{4}{*}{2013 01-05 } & $0.410 * * *$ & $0.194^{* * *}$ & 209 & 0.083 & NO \\
\hline & $(0.0294)$ & $(0.0501)$ & & & \\
\hline & $0.414^{* * *}$ & $0.178^{* * *}$ & 209 & 0.127 & YES \\
\hline & $(0.0286)$ & $(0.0489)$ & & & \\
\hline \multirow[t]{4}{*}{2014 01-05 } & $0.304 * * *$ & $0.524 * * *$ & 215 & 0.219 & $\mathrm{NO}$ \\
\hline & $(0.0910)$ & $(0.0668)$ & & & \\
\hline & $0.301 * * *$ & $0.526 * * *$ & 215 & 0.225 & YES \\
\hline & $(0.0913)$ & $(0.0671)$ & & & \\
\hline \multirow[t]{4}{*}{2015 01-05 } & $0.655^{* * *}$ & $0.353^{* * *}$ & 215 & 0.085 & $\mathrm{NO}$ \\
\hline & $(0.188)$ & $(0.105)$ & & & \\
\hline & $0.639 * * *$ & $0.363^{* * *}$ & 215 & 0.092 & YES \\
\hline & $(0.188)$ & $(0.105)$ & & & \\
\hline \multirow[t]{4}{*}{2016 01-05 } & $0.955^{* * *}$ & $0.535^{* * *}$ & 215 & 0.223 & $\mathrm{NO}$ \\
\hline & $(0.0247)$ & $(0.0884)$ & & & \\
\hline & $0.961 * * *$ & $0.518 * * *$ & 215 & 0.281 & YES \\
\hline & $(0.0240)$ & $(0.0849)$ & & & \\
\hline \multirow[t]{4}{*}{2017 01-05 } & $0.426^{* * *}$ & $0.538 * * *$ & 207 & 0.310 & $\mathrm{NO}$ \\
\hline & $(0.0696)$ & $(0.0647)$ & & & \\
\hline & $0.423 * * *$ & $0.541^{* * *}$ & 207 & 0.312 & YES \\
\hline & $(0.0700)$ & $(0.0651)$ & & & \\
\hline \multirow[t]{4}{*}{2018 01-03 } & $0.345^{* * *}$ & $0.729 * * *$ & 119 & 0.229 & $\mathrm{NO}$ \\
\hline & $(0.101)$ & $(0.134)$ & & & \\
\hline & $0.345^{* * *}$ & $0.729^{* * *}$ & 119 & 0.229 & YES \\
\hline & $(0.102)$ & $(0.137)$ & & & \\
\hline
\end{tabular}


Table 4. Basic Estimation Results (continued)

(1-c). Without supply shocks: Type III

\begin{tabular}{|c|c|c|c|c|c|}
\hline & $\begin{array}{l}\text { Constant } \\
\text { term }\end{array}$ & $\begin{array}{l}\text { Real GDP } \\
\text { growth } \\
\end{array}$ & \# of obs. & R-squared & $\begin{array}{l}\text { Horizon } \\
\text { dummies }\end{array}$ \\
\hline \multirow[t]{4}{*}{2011 06-12 } & $-1.054^{* * *}$ & $0.233 * * *$ & 316 & 0.378 & $\mathrm{NO}$ \\
\hline & $(0.0805)$ & (0.0323) & & & \\
\hline & $-0.562^{* * *}$ & $0.237 * * *$ & 316 & 0.538 & YES \\
\hline & $(0.107)$ & $(0.0425)$ & & & \\
\hline \multirow[t]{4}{*}{2012 06-12 } & $-0.273^{* * *}$ & $0.273^{* * *}$ & 306 & 0.226 & $\mathrm{NO}$ \\
\hline & $(0.0476)$ & $(0.0298)$ & & & \\
\hline & $-0.271 * * *$ & $0.271^{* * *}$ & 306 & 0.253 & YES \\
\hline & $(0.0509)$ & $(0.0318)$ & & & \\
\hline \multirow[t]{4}{*}{$201306-12$} & $0.501^{* * *}$ & $0.406 * * *$ & 311 & 0.205 & $\mathrm{NO}$ \\
\hline & (0.0334) & $(0.0624)$ & & & \\
\hline & $0.492 * * *$ & $0.419 * * *$ & 311 & 0.213 & YES \\
\hline & $(0.0367)$ & $(0.0689)$ & & & \\
\hline \multirow[t]{4}{*}{2014 06-12 } & $0.456^{* * *}$ & $0.478^{* * *}$ & 319 & 0.207 & $\mathrm{NO}$ \\
\hline & $(0.0877)$ & $(0.0615)$ & & & \\
\hline & $0.328 * * *$ & $0.569 * * *$ & 319 & 0.262 & YES \\
\hline & $(0.0890)$ & $(0.0610)$ & & & \\
\hline \multirow[t]{4}{*}{2015 06-12 } & $0.178^{* *}$ & $0.603^{* * *}$ & 311 & 0.205 & $\mathrm{NO}$ \\
\hline & $(0.0823)$ & $(0.0731)$ & & & \\
\hline & 0.186 & $0.538 * * *$ & 311 & 0.239 & YES \\
\hline & $(0.134)$ & $(0.0781)$ & & & \\
\hline \multirow[t]{4}{*}{$201606-12$} & $0.267 * * *$ & $0.452^{* * *}$ & 317 & 0.182 & $\mathrm{NO}$ \\
\hline & $(0.0619)$ & $(0.0626)$ & & & \\
\hline & $0.245^{* * *}$ & $0.476^{* * *}$ & 317 & 0.239 & YES \\
\hline & $(0.0604)$ & $(0.0622)$ & & & \\
\hline \multirow[t]{4}{*}{$201706-12$} & $0.302^{* * *}$ & $0.488^{* * *}$ & 291 & 0.179 & $\mathrm{NO}$ \\
\hline & $(0.0837)$ & $(0.0779)$ & & & \\
\hline & $0.272^{* * *}$ & $0.514^{* * *}$ & 291 & 0.206 & YES \\
\hline & $(0.0836)$ & $(0.0776)$ & & & \\
\hline
\end{tabular}


Table 4. Basic Estimation Results (continued)

(1-d). Without supply shocks: Type IV

\begin{tabular}{|c|c|c|c|c|c|}
\hline & $\begin{array}{l}\text { Constant } \\
\text { term }\end{array}$ & $\begin{array}{l}\text { Real GDP } \\
\text { growth }\end{array}$ & \# of obs. & R-squared & $\begin{array}{l}\text { Horizon } \\
\text { dummies }\end{array}$ \\
\hline \multirow[t]{4}{*}{2012 01-05 } & $-0.668^{* * *}$ & $0.182^{* * *}$ & 218 & 0.171 & $\mathrm{NO}$ \\
\hline & $(0.0933)$ & $(0.0479)$ & & & \\
\hline & $-0.492^{* * * *}$ & $0.193 * * *$ & 218 & 0.328 & YES \\
\hline & $(0.0944)$ & $(0.0488)$ & & & \\
\hline \multirow[t]{4}{*}{2013 01-05 } & $-0.192 * *$ & $0.197 * * *$ & 216 & 0.131 & $\mathrm{NO}$ \\
\hline & $(0.0790)$ & $(0.0378)$ & & & \\
\hline & -0.0821 & $0.144^{* * *}$ & 216 & 0.147 & YES \\
\hline & $(0.113)$ & $(0.0547)$ & & & \\
\hline \multirow[t]{4}{*}{2014 01-05 } & $0.803 * * *$ & $0.185^{* * *}$ & 224 & 0.060 & $\mathrm{NO}$ \\
\hline & $(0.0442)$ & $(0.0623)$ & & & \\
\hline & $0.786^{* * *}$ & $0.207 * * *$ & 224 & 0.098 & YES \\
\hline & $(0.0447)$ & $(0.0632)$ & & & \\
\hline \multirow[t]{4}{*}{2015 01-05 } & $0.151^{*}$ & $0.200^{* *}$ & 224 & 0.032 & $\mathrm{NO}$ \\
\hline & $(0.0801)$ & $(0.0826)$ & & & \\
\hline & 0.183 & $0.182^{* *}$ & 224 & 0.313 & YES \\
\hline & $(0.124)$ & $(0.0718)$ & & & \\
\hline \multirow[t]{4}{*}{2016 01-05 } & $-0.230 * * *$ & $0.557 * * *$ & 225 & 0.286 & $\mathrm{NO}$ \\
\hline & $(0.0847)$ & $(0.0745)$ & & & \\
\hline & 0.0696 & $0.291 * * *$ & 225 & 0.432 & YES \\
\hline & $(0.0911)$ & $(0.0801)$ & & & \\
\hline \multirow[t]{4}{*}{2017 01-05 } & $0.403 * * *$ & $0.330 * * *$ & 216 & 0.141 & $\mathrm{NO}$ \\
\hline & (0.0799) & $(0.0641)$ & & & \\
\hline & $0.369 * * *$ & $0.357 * * *$ & 216 & 0.155 & YES \\
\hline & (0.0903) & $(0.0724)$ & & & \\
\hline \multirow[t]{4}{*}{2018 01-03 } & $0.271^{*}$ & $0.509 * * *$ & 122 & 0.204 & $\mathrm{NO}$ \\
\hline & $(0.151)$ & $(0.122)$ & & & \\
\hline & $0.276^{*}$ & $0.505^{* * *}$ & 122 & 0.213 & YES \\
\hline & $(0.156)$ & $(0.126)$ & & & \\
\hline
\end{tabular}


Table 4. Basic Estimation Results (continued)

(2-a). Without supply shocks: Type II

\begin{tabular}{|c|c|c|c|c|c|c|c|}
\hline & Constant & Real GDP & NY WTI & USD/Yen & \# of obs. & $R$-squared & Horizon \\
\hline & term & growth & oil price & rate & & & dummies \\
\hline \multirow[t]{4}{*}{2012 01-05 } & $-0.155^{* *}$ & $0.202^{* * *}$ & 0.124 & -0.0438 & 158 & 0.123 & $\mathrm{NO}$ \\
\hline & $(0.0740)$ & $(0.0595)$ & $(0.438)$ & $(0.615)$ & & & \\
\hline & $-0.158^{*}$ & $0.203^{* * *}$ & 0.156 & -0.0243 & 158 & 0.142 & YES \\
\hline & $(0.0933)$ & $(0.0592)$ & $(0.431)$ & $(0.642)$ & & & \\
\hline \multirow[t]{4}{*}{2013 01-05 } & $0.395^{* * *}$ & $0.184 * * *$ & 0.286 & 0.121 & 163 & 0.087 & $\mathrm{NO}$ \\
\hline & $(0.0340)$ & $(0.0488)$ & $(0.517)$ & $(0.897)$ & & & \\
\hline & $0.404^{* * *}$ & $0.171^{* * *}$ & 0.221 & -0.0930 & 163 & 0.118 & YES \\
\hline & $(0.0351)$ & $(0.0478)$ & $(0.512)$ & $(0.889)$ & & & \\
\hline \multirow[t]{4}{*}{2014 01-05 } & $0.243 * * *$ & $0.488 * * *$ & $2.197 * * *$ & $2.962^{* *}$ & 162 & 0.365 & NO \\
\hline & $(0.0853)$ & $(0.0640)$ & $(0.591)$ & (1.186) & & & \\
\hline & $0.240 * * *$ & $0.492 * * *$ & $4.300 * * *$ & $2.772^{* *}$ & 162 & 0.380 & YES \\
\hline & $(0.0873)$ & $(0.0651)$ & $(0.595)$ & $(1.172)$ & & & \\
\hline \multirow[t]{4}{*}{2015 01-05 } & $0.411^{* *}$ & $0.335^{* * *}$ & $1.869 * * *$ & 2.319 & 167 & 0.154 & NO \\
\hline & $(0.192)$ & $(0.108)$ & $(0.579)$ & (1.777) & & & \\
\hline & $0.382^{* *}$ & $0.346^{* * *}$ & $1.994^{* * *}$ & 2.210 & 167 & 0.161 & YES \\
\hline & $(0.182)$ & $(0.106)$ & $(0.564)$ & $(1.735)$ & & & \\
\hline \multirow[t]{4}{*}{2016 01-05 } & $0.777 * * *$ & $0.428 * * *$ & $1.161^{* * *}$ & -0.903 & 169 & 0.238 & $\mathrm{NO}$ \\
\hline & $(0.0727)$ & $(0.0993)$ & $(0.420)$ & $(1.055)$ & & & \\
\hline & $0.746^{* * *}$ & $0.401^{* * *}$ & $1.331^{* * *}$ & 0.115 & 169 & 0.301 & YES \\
\hline & $(0.0718)$ & $(0.0967)$ & $(0.431)$ & $(1.088)$ & & & \\
\hline \multirow[t]{4}{*}{2017 01-05 } & $0.430 * * *$ & $0.476^{* * *}$ & $0.976^{* * *}$ & -1.462 & 188 & 0.353 & NO \\
\hline & $(0.0753)$ & $(0.0777)$ & $(0.336)$ & $(0.945)$ & & & \\
\hline & $0.429 * * *$ & $0.477 * * *$ & $0.982^{* * *}$ & $-1.439 * *$ & 188 & 0.354 & YES \\
\hline & $(0.0760)$ & $(0.0789)$ & $(0.343)$ & $(0.651)$ & & & \\
\hline \multirow[t]{4}{*}{2018 01-03 } & $0.342^{* * *}$ & $0.732 * * *$ & $1.685^{* * *}$ & 1.835 & 114 & 0.361 & $\mathrm{NO}$ \\
\hline & (0.0933) & $(0.124)$ & $(0.529)$ & $(1.311)$ & & & \\
\hline & $0.342^{* * *}$ & $0.731^{* * *}$ & $1.764^{* * *}$ & 1.647 & 114 & 0.367 & YES \\
\hline & $(0.0937)$ & $\quad(0.125)$ & $(0.544)$ & $(1.334)$ & & & \\
\hline
\end{tabular}


Table 4. Basic Estimation Results (continued)

(2-b). Without supply shocks: Type III

\begin{tabular}{|c|c|c|c|c|c|c|c|}
\hline & $\begin{array}{l}\text { Constant } \\
\text { term } \\
\end{array}$ & $\begin{array}{l}\text { Real GDP } \\
\text { growth }\end{array}$ & $\begin{array}{l}\text { NY WTI } \\
\text { oil price }\end{array}$ & $\begin{array}{l}\text { USD/Yen } \\
\text { rate }\end{array}$ & \# of obs. & $\mathrm{R}$-squared & $\begin{array}{l}\text { Horizon } \\
\text { dummies }\end{array}$ \\
\hline \multirow[t]{4}{*}{$201106-12$} & $-0.964^{* * *}$ & $0.293^{* * *}$ & $0.852^{* * *}$ & 0.970 & 239 & 0.390 & $\mathrm{NO}$ \\
\hline & $(0.0937)$ & $(0.0388)$ & $(0.373)$ & $(0.588)$ & & & \\
\hline & $-0.577^{* * *}$ & $0.244^{* * *}$ & 0.436 & 0.437 & 239 & 0.494 & YES \\
\hline & $(0.128)$ & $(0.0510)$ & $(0.332)$ & $(0.544)$ & & & \\
\hline \multirow[t]{4}{*}{2012 06-12 } & $-0.179 * * *$ & $0.238 * * *$ & $0.833^{* * *}$ & -1.72 & 232 & 0.258 & $\mathrm{NO}$ \\
\hline & $(0.0584)$ & (0.0363) & (0.191) & (1.448) & & & \\
\hline & $-0.168 * * *$ & $0.229 * * *$ & $0.843 * * *$ & $-1.677 * * *$ & 232 & 0.294 & YES \\
\hline & $(0.0623)$ & $(0.0385)$ & $(0.209)$ & $(0.461)$ & & & \\
\hline \multirow[t]{4}{*}{2013 06-12 } & $0.386^{* * *}$ & $0.432^{* * *}$ & $1.472^{* * *}$ & $1.932^{* * *}$ & 238 & 0.223 & $\mathrm{NO}$ \\
\hline & (0.0473) & $(0.0726)$ & $(0.491)$ & (0.723) & & & \\
\hline & $0.377^{* * *}$ & $0.447^{* * *}$ & $1.367^{* * *}$ & $1.956^{* * *}$ & 238 & 0.232 & YES \\
\hline & $(0.0505)$ & $(0.0807)$ & $(0.531)$ & $(0.741)$ & & & \\
\hline \multirow[t]{4}{*}{2014 06-12 } & $0.455^{* * *}$ & $0.470 * * *$ & $1.834^{* * *}$ & $1.799^{* *}$ & 240 & 0.276 & NO \\
\hline & (0.102) & $(0.0712)$ & (0.336) & (0.808) & & & \\
\hline & $0.436^{* * *}$ & $0.485^{* * *}$ & $1.833^{* * *}$ & $1.713^{* *}$ & 240 & 0.284 & YES \\
\hline & $(0.111)$ & $(0.0759)$ & $(0.471)$ & $(0.829)$ & & & \\
\hline \multirow[t]{4}{*}{2015 06-12 } & $0.271^{* *}$ & $0.454^{* * *}$ & $0.879 * * *$ & -1.026 & 257 & 0.177 & $\mathrm{NO}$ \\
\hline & $(0.118)$ & $(0.0747)$ & $(0.332)$ & (1.182) & & & \\
\hline & $0.345^{* *}$ & $0.422^{* * *}$ & 0.585 & -0.838 & 257 & 0.192 & YES \\
\hline & $(0.135)$ & $(0.0798)$ & $(0.363)$ & $(1.190)$ & & & \\
\hline \multirow[t]{4}{*}{2016 06-12 } & $0.162^{* *}$ & $0.332 * * *$ & $1.110^{* * *}$ & $2.659 * * *$ & 261 & 0.247 & $\mathrm{NO}$ \\
\hline & $(0.0710)$ & $(0.0664)$ & $(0.262)$ & (0.637) & & & \\
\hline & 0.106 & $0.366^{* * *}$ & $1.198 * * *$ & $3.224^{* * *}$ & 261 & 0.307 & YES \\
\hline & $(0.0728)$ & $(0.0640)$ & $(0.258)$ & $(0.750)$ & & & \\
\hline \multirow[t]{4}{*}{2017 06-12 } & $0.275^{* * *}$ & $0.401^{* * *}$ & $2.171^{* * *}$ & $1.505^{* * *}$ & 285 & 0.338 & NO \\
\hline & $(0.0898)$ & $(0.0884)$ & (0.321) & (0.519) & & & \\
\hline & $0.241 * * *$ & $0.424^{* * *}$ & $2.308^{* * *}$ & $1.591^{* * *}$ & 285 & 0.370 & YES \\
\hline & $(0.0901)$ & $(0.0878)$ & $(0.321)$ & $(0.526)$ & & & \\
\hline
\end{tabular}


Table 4. Basic Estimation Results (continued)

(2-c). Without supply shocks: Type IV

\begin{tabular}{|c|c|c|c|c|c|c|c|}
\hline & Constant & Real GDP & NY WTI & USD/Yen & \# of obs. & R-squared & Horizon \\
\hline & term & growth & oil price & rate & & & dummies \\
\hline \multirow[t]{4}{*}{$201201-05$} & $-0.604^{* * *}$ & $0.127^{* * *}$ & $0.823^{* * *}$ & $1.730^{* *}$ & 196 & 0.325 & $\mathrm{NO}$ \\
\hline & $(0.119)$ & $(0.0649)$ & $(0.216)$ & $(0.707)$ & & & \\
\hline & $-0.513 * * *$ & $0.187 * * *$ & $0.577 * *$ & $1.358^{*}$ & 196 & 0.379 & YES \\
\hline & $(0.116)$ & $(0.0633)$ & $(0.226)$ & $(0.729)$ & & & \\
\hline \multirow[t]{4}{*}{2013 01-05 } & $-0.197 * *$ & $0.144^{* * *}$ & $0.765^{* * *}$ & $0.802 * *$ & 198 & 0.228 & $\mathrm{NO}$ \\
\hline & $(0.0896)$ & $(0.0549)$ & $(0.249)$ & $(0.359)$ & & & \\
\hline & -0.193 & $0.142 * *$ & $0.763^{* * *}$ & 0.806 & 198 & 0.230 & YES \\
\hline & $(0.118)$ & $(0.0600)$ & $(0.262)$ & $(0.502)$ & & & \\
\hline \multirow[t]{4}{*}{$201401-05$} & $0.733^{* * *}$ & $0.143^{* *}$ & 0.584 & $2.014^{* * *}$ & 202 & 0.104 & NO \\
\hline & $(0.0553)$ & $(0.0684)$ & $(0.385)$ & $(0.660)$ & & & \\
\hline & $0.707 * * *$ & $0.167^{* *}$ & 0.607 & $2.146^{* * *}$ & 202 & 0.153 & YES \\
\hline & $(0.0560)$ & $(0.0696)$ & $(0.393)$ & $(0.657)$ & & & \\
\hline \multirow[t]{4}{*}{2015 01-05 } & $0.454^{* * *}$ & $0.184^{* * *}$ & $1.752^{* * *}$ & 1.067 & 207 & 0.345 & $\mathrm{NO}$ \\
\hline & $(0.149)$ & $(0.0656)$ & (0.199) & $(0.963)$ & & & \\
\hline & $0.674 * * *$ & $0.148 * *$ & $1.462 * * *$ & 0.549 & 207 & 0.452 & YES \\
\hline & $(0.167)$ & $(0.0636)$ & $(0.238)$ & $(0.872)$ & & & \\
\hline \multirow[t]{4}{*}{2016 01-05 } & $0.343 * * *$ & $0.206^{* * *}$ & $0.874^{* * *}$ & $2.387 * * *$ & 214 & 0.440 & $\mathrm{NO}$ \\
\hline & $(0.105)$ & $(0.0775)$ & $(0.192)$ & $(0.500)$ & & & \\
\hline & $0.315^{* * *}$ & $0.177^{* *}$ & $0.708^{* * *}$ & 0.746 & 214 & 0.473 & YES \\
\hline & (0.108) & $(0.0781)$ & $(0.246)$ & $(0.737)$ & & & \\
\hline \multirow[t]{4}{*}{2017 01-05 } & $0.266^{* * *}$ & $0.313^{* * *}$ & $0.952^{* * *}$ & $0.980 * *$ & 214 & 0.210 & $\mathrm{NO}$ \\
\hline & $(0.0980)$ & $(0.0622)$ & $(0.338)$ & $(0.421)$ & & & \\
\hline & $0.240 * *$ & $0.338 * * *$ & $0.941 * * *$ & $0.887 * *$ & 214 & 0.217 & YES \\
\hline & $(0.106)$ & $(0.0692)$ & $(0.340)$ & $(0.413)$ & & & \\
\hline \multirow[t]{4}{*}{2018 01-03 } & $0.125^{* * *}$ & $0.548 * * *$ & $0.868^{* * *}$ & 0.732 & 122 & 0.270 & $\mathrm{NO}$ \\
\hline & $(0.0601)$ & $(0.128)$ & $(0.304)$ & $(0.700)$ & & & \\
\hline & 0.128 & $0.552 * * *$ & $0.736 * *$ & 1.103 & 122 & 0.273 & YES \\
\hline & $(0.163)$ & $(0.131)$ & $(0.321)$ & $(0.749)$ & & & \\
\hline
\end{tabular}

Note 1) Robust standard errors in parentheses.

2) $* * * \mathrm{p}<0.01, * * \mathrm{p}<0.05, * \mathrm{p}<0.1$. 
Table 5. Estimation Results with Instrumental Variables

(1-a). Without supply shocks: Type I

\begin{tabular}{|c|c|c|c|c|c|}
\hline & \begin{tabular}{|l} 
Constant \\
term \\
\end{tabular} & $\begin{array}{l}\text { Real GDP } \\
\text { growth }\end{array}$ & \# of obs. & R-squared & $\begin{array}{l}\text { Horizon } \\
\text { dummies }\end{array}$ \\
\hline \multirow[t]{4}{*}{2013 06-12 } & $0.250 * * *$ & $0.555^{* * *}$ & 243 & 0.257 & $\mathrm{NO}$ \\
\hline & (0.0768) & $(0.0623)$ & & & \\
\hline & $0.250 * * *$ & $0.555^{* * *}$ & 243 & 0.261 & YES \\
\hline & $(0.0768)$ & $(0.0623)$ & & & \\
\hline \multirow[t]{4}{*}{2014 06-12 } & $1.043^{* * *}$ & 0.198 & 244 & 0.024 & $\mathrm{NO}$ \\
\hline & $(0.209)$ & $(0.154)$ & & & \\
\hline & $1.041^{* * *}$ & 0.200 & 244 & 0.025 & YES \\
\hline & $(0.203)$ & $(0.150)$ & & & \\
\hline \multirow[t]{4}{*}{$201506-12$} & $1.220 * * *$ & $0.215^{* *}$ & 225 & 0.053 & $\mathrm{NO}$ \\
\hline & $(0.0268)$ & $(0.0845)$ & & & \\
\hline & $1.221^{* * *}$ & $0.211^{* *}$ & 225 & 0.063 & YES \\
\hline & $(0.0268)$ & $(0.0848)$ & & & \\
\hline \multirow[t]{4}{*}{$201606-12$} & $0.274 * * *$ & $0.714^{* * *}$ & 236 & 0.473 & $\mathrm{NO}$ \\
\hline & $(0.0494)$ & $(0.0474)$ & & & \\
\hline & $0.274 * * *$ & $0.715^{* * *}$ & 236 & 0.475 & YES \\
\hline & $(0.0498)$ & $(0.0474)$ & & & \\
\hline \multirow[t]{4}{*}{$201706-12$} & $0.652 * * *$ & $0.492 * * *$ & 220 & 0.102 & $\mathrm{NO}$ \\
\hline & $(0.101)$ & $(0.137)$ & & & \\
\hline & $0.654^{* * *}$ & $0.489 * * *$ & 220 & 0.108 & YES \\
\hline & $(0.0997)$ & $(0.136)$ & & & \\
\hline
\end{tabular}


Table 5. Estimation Results with Instrumental Variables (continued)

(1-b). Without supply shocks: Type II

\begin{tabular}{|c|c|c|c|c|c|}
\hline & $\begin{array}{l}\text { Constant } \\
\text { term } \\
\end{array}$ & $\begin{array}{l}\text { Real GDP } \\
\text { growth } \\
\end{array}$ & \# of obs. & R-squared & \begin{tabular}{|l} 
Horizon \\
dummies
\end{tabular} \\
\hline \multirow[t]{4}{*}{2012 01-05 } & $-0.236^{*}$ & $0.257 * * *$ & 122 & 0.134 & $\mathrm{NO}$ \\
\hline & (0.129) & $(0.0890)$ & & & \\
\hline & $-0.227^{*}$ & $0.249 * * *$ & 122 & 0.157 & YES \\
\hline & $(0.129)$ & $(0.0891)$ & & & \\
\hline \multirow[t]{4}{*}{2013 01-05 } & $0.461^{* * *}$ & $0.156^{* * *}$ & 128 & 0.096 & $\mathrm{NO}$ \\
\hline & $(0.0219)$ & $(0.0460)$ & & & \\
\hline & $0.463 * * *$ & $0.150 * * *$ & 128 & 0.106 & YES \\
\hline & $(0.0221)$ & $(0.0464)$ & & & \\
\hline \multirow[t]{4}{*}{2014 01-05 } & $0.345^{* * *}$ & $0.512^{* * *}$ & 128 & 0.237 & $\mathrm{NO}$ \\
\hline & $(0.112)$ & $(0.0821)$ & & & \\
\hline & $0.344 * * *$ & $0.511 * * *$ & 128 & 0.242 & YES \\
\hline & $(0.111)$ & $(0.0812)$ & & & \\
\hline \multirow[t]{4}{*}{$201501-05$} & $0.609 * *$ & $0.364 * * *$ & 132 & 0.084 & $\mathrm{NO}$ \\
\hline & $(0.243)$ & $(0.136)$ & & & \\
\hline & $0.602^{* *}$ & $0.369 * * *$ & 132 & 0.085 & YES \\
\hline & $(0.242)$ & $(0.136)$ & & & \\
\hline \multirow[t]{4}{*}{$201601-05$} & $0.921 * * *$ & $0.481^{* * *}$ & 133 & 0.146 & $\mathrm{NO}$ \\
\hline & $(0.0327)$ & $(0.130)$ & & & \\
\hline & $0.927 * * *$ & $0.456^{* * *}$ & 133 & 0.193 & YES \\
\hline & $(0.0321)$ & $(0.126)$ & & & \\
\hline \multirow[t]{4}{*}{2017 01-05 } & $0.303^{* * *}$ & $0.639^{* * *}$ & 146 & 0.324 & $\mathrm{NO}$ \\
\hline & $(0.0963)$ & $(0.0851)$ & & & \\
\hline & $0.304^{* * *}$ & $0.639 * * *$ & 146 & 0.325 & YES \\
\hline & $(0.0959)$ & $(0.0848)$ & & & \\
\hline \multirow[t]{3}{*}{2018 01-03 } & $0.284^{* *}$ & $0.807 * * *$ & 74 & 0.233 & $\mathrm{NO}$ \\
\hline & $(0.120)$ & $(0.161)$ & & & \\
\hline & $0.283^{* *}$ & $0.809 * * *$ & 74 & 0.234 & YES \\
\hline
\end{tabular}


Table 5. Estimation Results with Instrumental Variables (continued)

(1-c). Without supply shocks: Type III

\begin{tabular}{|c|c|c|c|c|c|}
\hline & \begin{tabular}{|l|} 
Constant \\
term
\end{tabular} & $\begin{array}{l}\text { Real GDP } \\
\text { growth } \\
\end{array}$ & \# of obs. & R-squared & $\begin{array}{l}\text { Horizon } \\
\text { dummies }\end{array}$ \\
\hline \multirow[t]{4}{*}{2011 06-12 } & $-0.911 * * *$ & $0.369 * * *$ & 202 & 0.389 & $\mathrm{NO}$ \\
\hline & (0.107) & $(0.0452)$ & & & \\
\hline & $-0.690 * * *$ & $0.279 * * *$ & 202 & 0.487 & YES \\
\hline & $(0.146)$ & $(0.0605)$ & & & \\
\hline \multirow[t]{4}{*}{2012 06-12 } & $-0.261^{* * *}$ & $0.263^{* * *}$ & 200 & 0.137 & $\mathrm{NO}$ \\
\hline & $(0.0885)$ & $(0.0562)$ & & & \\
\hline & $-0.267 * * *$ & $0.267 * * *$ & 200 & 0.156 & YES \\
\hline & $(0.0919)$ & $(0.0584)$ & & & \\
\hline \multirow[t]{4}{*}{$201306-12$} & $0.494 * * *$ & $0.416^{* * *}$ & 201 & 0.177 & NO \\
\hline & $(0.0502)$ & (0.0893) & & & \\
\hline & $0.481^{* * *}$ & $0.434^{* * *}$ & 201 & 0.190 & YES \\
\hline & $(0.0539)$ & $(0.0948)$ & & & \\
\hline \multirow[t]{4}{*}{2014 06-12 } & $0.310^{* *}$ & $0.585^{* * *}$ & 204 & 0.120 & $\mathrm{NO}$ \\
\hline & (0.139) & $(0.0987)$ & & & \\
\hline & $0.223^{*}$ & $0.650 * * *$ & 204 & 0.185 & YES \\
\hline & $(0.135)$ & $(0.0948)$ & & & \\
\hline \multirow[t]{4}{*}{2015 06-12 } & 0.178 & $0.535^{* * *}$ & 219 & 0.159 & $\mathrm{NO}$ \\
\hline & $(0.146)$ & $(0.0852)$ & & & \\
\hline & $0.262^{*}$ & $0.483^{* * *}$ & 219 & 0.188 & YES \\
\hline & $(0.152)$ & $(0.0883)$ & & & \\
\hline \multirow[t]{4}{*}{2016 06-12 } & $0.185^{* *}$ & $0.503^{* * *}$ & 219 & 0.175 & NO \\
\hline & $(0.0838)$ & $(0.0873)$ & & & \\
\hline & $0.173^{* *}$ & $0.518 * * *$ & 219 & 0.217 & YES \\
\hline & $(0.0791)$ & $(0.0826)$ & & & \\
\hline \multirow[t]{4}{*}{2017 06-12 } & $0.222^{* * *}$ & $0.546^{* * *}$ & 242 & 0.175 & NO \\
\hline & (0.101) & $(0.0918)$ & & & \\
\hline & $0.207^{* *}$ & $0.558^{* * *}$ & 242 & 0.191 & YES \\
\hline & $(0.100)$ & $(0.0912)$ & & & \\
\hline
\end{tabular}


Table 5. Estimation Results with Instrumental Variables (continued)

(1-d). Without supply shocks: Type IV

\begin{tabular}{|c|c|c|c|c|c|}
\hline & \begin{tabular}{|l} 
Constant \\
term
\end{tabular} & $\begin{array}{l}\text { Real GDP } \\
\text { growth }\end{array}$ & $\#$ of obs. & R-squared & \begin{tabular}{|l} 
Horizon \\
dummies
\end{tabular} \\
\hline \multirow[t]{4}{*}{2012 01-05 } & $-0.806^{* * *}$ & $0.365 * * *$ & 154 & 0.086 & $\mathrm{NO}$ \\
\hline & $(0.165)$ & $(0.0836)$ & & & \\
\hline & $-0.576^{* * *}$ & $0.249 * * *$ & 154 & 0.285 & YES \\
\hline & $(0.157)$ & $(0.0809)$ & & & \\
\hline \multirow[t]{4}{*}{2013 01-05 } & $-0.305^{* *}$ & $0.255^{* * *}$ & 156 & 0.098 & $\mathrm{NO}$ \\
\hline & $(0.153)$ & $(0.0689)$ & & & \\
\hline & -0.206 & $0.210^{* *}$ & 156 & 0.112 & YES \\
\hline & $(0.200)$ & $(0.0892)$ & & & \\
\hline \multirow[t]{4}{*}{2014 01-05 } & $0.797 * * *$ & $0.216 * * *$ & 161 & 0.055 & $\mathrm{NO}$ \\
\hline & $(0.0560)$ & $(0.0795)$ & & & \\
\hline & $0.784^{* * *}$ & $0.232^{* * *}$ & 161 & 0.078 & YES \\
\hline & $(0.0555)$ & $(0.0790)$ & & & \\
\hline \multirow[t]{4}{*}{$201501-05$} & $-0.274^{*}$ & $0.394 * * *$ & 165 & 0.064 & $\mathrm{NO}$ \\
\hline & $(0.160)$ & $(0.0952)$ & & & \\
\hline & -0.180 & $0.342^{* * *}$ & 165 & 0.148 & YES \\
\hline & $(0.150)$ & $(0.0887)$ & & & \\
\hline \multirow[t]{4}{*}{$201601-05$} & $-0.158^{*}$ & $0.447 * * *$ & 166 & 0.182 & $\mathrm{NO}$ \\
\hline & $(0.0951)$ & $(0.0902)$ & & & \\
\hline & -0.00505 & $0.302^{* * *}$ & 166 & 0.248 & YES \\
\hline & $(0.102)$ & $(0.0970)$ & & & \\
\hline \multirow[t]{4}{*}{2017 01-05 } & $0.351 * * *$ & $0.372 * * *$ & 166 & 0.077 & $\mathrm{NO}$ \\
\hline & $(0.112)$ & $(0.0872)$ & & & \\
\hline & $0.294^{* *}$ & $0.416^{* * *}$ & 166 & 0.084 & YES \\
\hline & $(0.122)$ & $(0.0944)$ & & & \\
\hline \multirow[t]{4}{*}{2018 01-03 } & 0.291 & $0.505^{* * *}$ & 80 & 0.270 & $\mathrm{NO}$ \\
\hline & (0.198) & $(0.159)$ & & & \\
\hline & 0.293 & $0.504^{* * *}$ & 80 & 0.270 & YES \\
\hline & $(0.198)$ & $(0.160)$ & & & \\
\hline
\end{tabular}


Table 5. Estimation Results with Instrumental Variables (continued)

(2-a). Without supply shocks: Type II

\begin{tabular}{|c|c|c|c|c|c|c|c|}
\hline & Constant & Real GDP & NY WTI & USD/Yen & $\#$ of obs. & R-squared & Horizon \\
\hline & term & growth & oil price & rate & & & dummies \\
\hline \multirow{4}{*}{2012 01-05 } & -0.186 & $0.222^{* * *}$ & 0.466 & 0.0314 & 120 & 0.146 & $\mathrm{NO}$ \\
\hline & $(0.132)$ & $(0.0859)$ & $(0.509)$ & (0.711) & & & \\
\hline & -0.185 & $0.218^{* *}$ & 0.520 & 0.0568 & 120 & 0.166 & YES \\
\hline & $(0.131)$ & $(0.0855)$ & $(0.490)$ & $(0.722)$ & & & \\
\hline \multirow[t]{4}{*}{2013 01-05 } & $0.428^{* * *}$ & $0.162^{* * *}$ & -0.0230 & $1.494^{*}$ & 128 & 0.117 & $\mathrm{NO}$ \\
\hline & $(0.0343)$ & $(0.0462)$ & $(0.524)$ & $(0.844)$ & & & \\
\hline & $0.432^{* * * *}$ & $0.157^{* * *}$ & -0.0401 & $1.402^{*}$ & 128 & 0.124 & YES \\
\hline & $(0.0346)$ & $(0.0464)$ & $(0.525)$ & $(0.846)$ & & & \\
\hline \multirow{4}{*}{$201401-05$} & $0.250^{* * * *}$ & $0.498^{* * *}$ & $4.158^{* * * *}$ & $2.805^{* *}$ & 126 & 0.394 & NO \\
\hline & $(0.0932)$ & $(0.0702)$ & $(0.620)$ & (1.288) & & & \\
\hline & $0.248^{* * * *}$ & $0.498^{* * * *}$ & $4.236^{* * * *}$ & $2.767^{* *}$ & 126 & 0.403 & YES \\
\hline & $(0.0929)$ & $(0.0695)$ & $(0.612)$ & (1.258) & & & \\
\hline \multirow[t]{4}{*}{$201501-05$} & $0.402^{* * *}$ & $0.407^{* * *}$ & $2.069 * * *$ & 2.664 & 131 & 0.195 & $\mathrm{NO}$ \\
\hline & (0.168) & (0.108) & $(0.638)$ & (1.797) & & & \\
\hline & $0.401^{* * * *}$ & $0.408^{* * *}$ & $2.067^{* * *}$ & 2.648 & 131 & 0.195 & YES \\
\hline & $(0.167)$ & $(0.108)$ & $(0.639)$ & $(1.780)$ & & & \\
\hline \multirow[t]{4}{*}{$201601-05$} & $0.672^{* * *}$ & $0.380 * * *$ & $1.541^{* * *}$ & 0.108 & 127 & 0.223 & $\mathrm{NO}$ \\
\hline & $(0.0884)$ & $(0.130)$ & $(0.498)$ & (1.168) & & & \\
\hline & $0.687^{* * * *}$ & $0.362^{* * * *}$ & $1.433^{* * * *}$ & 0.579 & 127 & 0.259 & YES \\
\hline & $(0.0846)$ & $(0.127)$ & $(0.491)$ & (1.172) & & & \\
\hline \multirow[t]{4}{*}{2017 01-05 } & $0.366^{* * * *}$ & $0.526^{* * *}$ & $1.104^{* * *}$ & $-1.259^{*}$ & 145 & 0.370 & $\mathrm{NO}$ \\
\hline & $(0.0959)$ & $(0.100)$ & $(0.423)$ & $(0.655)$ & & & \\
\hline & $0.367^{* * * *}$ & $0.525^{* * *}$ & $1.109^{* * * *}$ & $-1.255^{*}$ & 145 & 0.371 & YES \\
\hline & $(0.0955)$ & $(0.0999)$ & $(0.427)$ & $(0.657)$ & & & \\
\hline \multirow[t]{4}{*}{2018 01-03 } & $0.293^{* *}$ & $0.819 * * *$ & $1.589^{* * * *}$ & 0.588 & 73 & 0.342 & NO \\
\hline & (0.118) & $(0.158)$ & $(0.564)$ & $(1.782)$ & & & \\
\hline & $0.292 * *$ & $0.821^{* * *}$ & $1.592^{* * * *}$ & 0.568 & 73 & 0.342 & YES \\
\hline & $(0.117)$ & $(0.157)$ & $(0.571)$ & $(1.756)$ & & & \\
\hline
\end{tabular}


Table 5. Estimation Results with Instrumental Variables (continued)

(2-b). Without supply shocks: Type III

\begin{tabular}{|c|c|c|c|c|c|c|c|}
\hline & Constant & Real GDP & NY WTI & USD/Yen & $\#$ of obs. & R-squared & Horizon \\
\hline & term & growth & oil price & rate & & & dummies \\
\hline \multirow[t]{4}{*}{$201106-12$} & $-0.964^{* * *}$ & $0.386^{* * *}$ & $0.779^{*}$ & 0.649 & 196 & 0.418 & $\mathrm{NO}$ \\
\hline & $(0.0996)$ & $(0.0442)$ & (0.436) & $(0.607)$ & & & \\
\hline & $-0.766^{* * *}$ & $0.310 * * *$ & 0.522 & 0.197 & 196 & 0.490 & YES \\
\hline & $(0.142)$ & $(0.0591)$ & $(0.391)$ & $(0.544)$ & & & \\
\hline \multirow[t]{4}{*}{2012 06-12 } & $-0.186^{* *}$ & $0.230 * * *$ & $0.916^{* * *}$ & $1.492^{* * *}$ & 197 & 0.227 & $\mathrm{NO}$ \\
\hline & (0.0767) & $(0.0467)$ & $(0.221)$ & (0.479) & & & \\
\hline & $-0.196 * *$ & $0.236^{* * *}$ & $0.923^{* * *}$ & $1.479^{* * *}$ & 197 & 0.246 & YES \\
\hline & $(0.0787)$ & $(0.0478)$ & $(0.223)$ & $(0.472)$ & & & \\
\hline \multirow[t]{4}{*}{2013 06-12 } & $0.352^{* * * *}$ & $0.462^{* * *}$ & $1.721^{* * * *}$ & $2.183^{* * *}$ & 198 & 0.233 & NO \\
\hline & $(0.0617)$ & $(0.0936)$ & $(0.552)$ & (0.746) & & & \\
\hline & $0.342^{* * * *}$ & $0.481^{* * *}$ & $1.567^{* * * *}$ & $2.186^{* * *}$ & 198 & 0.245 & YES \\
\hline & $(0.0653)$ & $(0.101)$ & $(0.586)$ & (0.778) & & & \\
\hline \multirow[t]{4}{*}{2014 06-12 } & $0.269^{* *}$ & $0.610 * * *$ & $1.848^{* * *}$ & 1.623 & 199 & 0.234 & NO \\
\hline & $(0.137)$ & $(0.0954)$ & $(0.373)$ & (0.988) & & & \\
\hline & 0.206 & $0.638^{* * *}$ & $1.536^{* * * *}$ & $1.933^{*}$ & 199 & 0.243 & YES \\
\hline & $(0.147)$ & $(0.0956)$ & $(0.528)$ & $(1.027)$ & & & \\
\hline \multirow[t]{4}{*}{$201506-12$} & $0.233^{*}$ & $0.482^{* * *}$ & $0.731^{* *}$ & -1.581 & 218 & 0.185 & $\mathrm{NO}$ \\
\hline & $(0.128)$ & $(0.0813)$ & $(0.346)$ & (1.115) & & & \\
\hline & $0.286^{* *}$ & $0.458^{* * *}$ & 0.493 & -1.380 & 218 & 0.199 & YES \\
\hline & $(0.138)$ & $(0.0834)$ & $(0.363)$ & (1.113) & & & \\
\hline \multirow[t]{4}{*}{2016 06-12 } & 0.101 & $0.388^{* * *}$ & $1.032^{* * * *}$ & $2.443^{* * *}$ & 219 & 0.258 & $\mathrm{NO}$ \\
\hline & $(0.0842)$ & $(0.0832)$ & $(0.292)$ & (0.661) & & & \\
\hline & 0.0459 & $0.411^{* * *}$ & $1.171^{* * *}$ & $3.166^{* * *}$ & 219 & 0.309 & YES \\
\hline & $(0.0841)$ & $(0.0761)$ & $(0.287)$ & $(0.801)$ & & & \\
\hline \multirow[t]{4}{*}{2017 06-12 } & $0.228^{* * *}$ & $0.438^{* * *}$ & $2.033^{* * * *}$ & $1.705^{* * *}$ & 242 & 0.335 & NO \\
\hline & $(0.102)$ & $(0.0986)$ & $(0.334)$ & $(0.565)$ & & & \\
\hline & $0.204^{* *}$ & $0.450 * * *$ & $2.220^{* * * *}$ & $1.809^{* * *}$ & 242 & 0.364 & YES \\
\hline & $(0.100)$ & $(0.0961)$ & (0.333) & $(0.568)$ & & & \\
\hline
\end{tabular}


Table 5. Estimation Results with Instrumental Variables (continued)

(2-c). Without supply shocks: Type IV

\begin{tabular}{|c|c|c|c|c|c|c|c|}
\hline & Constant & Real GDP & NY WTI & USD/Yen & \# of obs. & R-squared & Horizon \\
\hline & term & growth & oil price & rate & & & dummies \\
\hline \multirow{4}{*}{2012 01-05 } & $-0.710^{* * *}$ & $0.279 * * *$ & $1.059^{* * * *}$ & 1.387 & 151 & 0.263 & NO \\
\hline & (0.199) & (0.106) & $(0.254)$ & $(0.844)$ & & & \\
\hline & $-0.581^{* * *}$ & $0.223^{* *}$ & $0.801^{* * *}$ & 1.014 & 151 & 0.345 & YES \\
\hline & $(0.186)$ & $(0.0991)$ & $(0.260)$ & $(0.829)$ & & & \\
\hline \multirow[t]{4}{*}{2013 01-05 } & $-0.313^{* *}$ & $0.215^{* *}$ & $0.754^{* * *}$ & 0.480 & 156 & 0.145 & NO \\
\hline & $(0.160)$ & $(0.0840)$ & $(0.274)$ & $(0.470)$ & & & \\
\hline & -0.264 & $0.196^{* *}$ & $0.760^{* * * *}$ & 0.405 & 156 & 0.150 & YES \\
\hline & $(0.203)$ & $(0.0929)$ & $(0.284)$ & $(0.611)$ & & & \\
\hline \multirow[t]{4}{*}{$201401-05$} & $0.730^{* * * *}$ & $0.169^{* *}$ & 0.428 & $2.112^{* * *}$ & 160 & 0.106 & NO \\
\hline & $(0.0671)$ & $(0.0853)$ & $(0.441)$ & $(0.761)$ & & & \\
\hline & $0.712^{* * * *}$ & $0.193^{* *}$ & 0.324 & $2.107 * * *$ & 160 & 0.129 & YES \\
\hline & $(0.0660)$ & $(0.0850)$ & $(0.440)$ & $(0.735)$ & & & \\
\hline \multirow[t]{4}{*}{2015 01-05 } & 0.224 & $0.305^{* * *}$ & $1.106^{* * *}$ & 0.686 & 163 & 0.203 & NO \\
\hline & $(0.235)$ & $(0.0846)$ & $(0.284)$ & (1.214) & & & \\
\hline & $0.462^{*}$ & $0.219 * * *$ & $1.316^{* * *}$ & 0.609 & 163 & 0.318 & YES \\
\hline & $(0.245)$ & $(0.0821)$ & $(0.266)$ & $(1.052)$ & & & \\
\hline \multirow[t]{4}{*}{2016 01-05 } & $0.282^{* *}$ & $0.234^{* *}$ & $0.762^{* * * *}$ & $2.148^{* * *}$ & 162 & 0.313 & NO \\
\hline & (0.137) & $(0.0958)$ & $(0.220)$ & $(0.601)$ & & & \\
\hline & $0.359^{* *}$ & $0.164^{*}$ & $0.968^{* * * *}$ & $1.268^{*}$ & 162 & 0.351 & YES \\
\hline & $(0.140)$ & $(0.0969)$ & $(0.262)$ & $(0.719)$ & & & \\
\hline \multirow[t]{4}{*}{2017 01-05 } & 0.183 & $0.359 * * *$ & $1.248^{* * *}$ & $0.837^{*}$ & 166 & 0.181 & NO \\
\hline & $(0.131)$ & $(0.0827)$ & $(0.366)$ & $(0.482)$ & & & \\
\hline & 0.148 & $0.392^{* * * *}$ & $1.252^{* * * *}$ & 0.713 & 166 & 0.182 & YES \\
\hline & $(0.136)$ & $(0.0875)$ & $(0.363)$ & $(0.469)$ & & & \\
\hline \multirow[t]{4}{*}{2018 01-03 } & 0.152 & $0.547^{* * *}$ & $0.696^{*}$ & 0.737 & 80 & 0.326 & NO \\
\hline & $(0.203)$ & (0.163) & $(0.377)$ & $(0.872)$ & & & \\
\hline & 0.156 & $0.547 * * *$ & $0.653^{*}$ & 0.906 & 80 & 0.329 & YES \\
\hline & $(0.203)$ & $(0.164)$ & $(0.367)$ & $(0.849)$ & & & \\
\hline
\end{tabular}

Note 1) Robust standard errors in parentheses.

2) $* * * \mathrm{p}<0.01, * * \mathrm{p}<0.05, * \mathrm{p}<0.1$ 
Table 6. Estimation Results with Additional Exogenous Shocks

(a). Without supply shocks: Type II

\begin{tabular}{|c|c|c|c|c|c|c|c|c|c|}
\hline & Constant & Real GDP & NY WTI & USD/Yen & US GDP & China GDP & \# of obs. & $\mathrm{R}$-squared & Horizon \\
\hline & term & growth & oil price & rate & growth & growth & & & dummies \\
\hline \multirow[t]{4}{*}{$201201-05$} & $-0.217^{* *}$ & $0.194^{* * *}$ & -0.393 & -0.508 & $0.202^{* * *}$ & 0.0461 & 156 & 0.229 & NO \\
\hline & $(0.105)$ & $(0.0565)$ & $(0.393)$ & $(0.572)$ & $(0.0429)$ & $(0.0582)$ & & & \\
\hline & $-0.213^{* *}$ & $0.197^{* * * *}$ & -0.369 & -0.513 & $0.199 * * *$ & 0.0547 & 156 & 0.249 & YES \\
\hline & $(0.105)$ & $(0.0565)$ & $(0.380)$ & $(0.597)$ & $(0.0436)$ & $(0.0587)$ & & & \\
\hline \multirow[t]{4}{*}{2013 01-05 } & $0.349 * * *$ & $0.176^{* * *}$ & 0.318 & 0.0332 & 0.110 & 0.0169 & 162 & 0.102 & NO \\
\hline & $(0.0434)$ & $(0.0521)$ & $(0.591)$ & $(0.873)$ & $(0.0692)$ & (0.107) & & & \\
\hline & $0.353^{* * *}$ & $0.167^{* * *}$ & 0.160 & -0.244 & $0.116^{*}$ & 0.0506 & 162 & 0.134 & YES \\
\hline & $(0.0433)$ & $(0.0497)$ & $(0.609)$ & $(0.873)$ & (0.0699) & $(0.112)$ & & & \\
\hline \multirow[t]{4}{*}{2014 01-05 } & -0.0270 & $0.501^{* * *}$ & $4.627^{* * *}$ & $4.072^{* * *}$ & 0.156 & -0.106 & 159 & 0.413 & NO \\
\hline & $(0.167)$ & $(0.0681)$ & (0.674) & (1.158) & $(0.108)$ & $(0.0704)$ & & & \\
\hline & -0.00941 & $0.503^{* * *}$ & $4.665^{* * *}$ & $3.875^{* * *}$ & 0.143 & -0.0988 & 159 & 0.420 & YES \\
\hline & $(0.171)$ & $(0.0691)$ & $(0.694)$ & (1.145) & $(0.111)$ & $(0.0724)$ & & & \\
\hline \multirow[t]{4}{*}{2015 01-05 } & $0.406^{*}$ & $0.323^{* * *}$ & $1.874^{* * *}$ & 1.919 & 0.248 & 0.108 & 165 & 0.168 & NO \\
\hline & $(0.244)$ & $(0.110)$ & (0.611) & (1.801) & $(0.164)$ & (0.138) & & & \\
\hline & 0.357 & $0.337^{* * *}$ & $2.002^{* * *}$ & 1.922 & 0.239 & 0.0819 & 165 & 0.173 & YES \\
\hline & $(0.236)$ & $(0.107)$ & $(0.596)$ & $(1.781)$ & $(0.170)$ & $(0.159)$ & & & \\
\hline \multirow[t]{4}{*}{$201601-05$} & $1.101^{* * *}$ & $0.389^{* * *}$ & $0.958^{* *}$ & -0.920 & 0.0780 & $0.458^{* * *}$ & 168 & 0.331 & $\mathrm{NO}$ \\
\hline & (0.109) & $(0.0906)$ & $(0.416)$ & $(1.075)$ & $(0.111)$ & $(0.104)$ & & & \\
\hline & $1.027^{* * *}$ & $0.378^{* * *}$ & $1.109^{* *}$ & -0.173 & 0.0312 & $0.414^{* * *}$ & 168 & 0.374 & YES \\
\hline & $(0.112)$ & $(0.0902)$ & $(0.439)$ & $(1.098)$ & $(0.108)$ & $(0.103)$ & & & \\
\hline \multirow[t]{4}{*}{2017 01-05 } & $0.338^{* *}$ & $0.473^{* * *}$ & $0.920 * * *$ & -1.192 & $0.133^{*}$ & 0.0788 & 183 & 0.372 & NO \\
\hline & $(0.144)$ & $(0.0866)$ & $(0.330)$ & $(0.773)$ & $(0.0691)$ & $(0.136)$ & & & \\
\hline & $0.339^{* *}$ & $0.474^{* * *}$ & $0.923^{* * *}$ & -1.167 & $0.135^{*}$ & 0.0852 & 183 & 0.373 & YES \\
\hline & $(0.147)$ & $(0.0876)$ & $(0.335)$ & $(0.780)$ & $(0.0710)$ & $(0.137)$ & & & \\
\hline \multirow[t]{4}{*}{2018 01-03 } & $0.681^{* * *}$ & $0.745^{* * *}$ & $1.644^{* * *}$ & $3.933^{* * *}$ & $-0.257^{* * *}$ & $0.590^{* * *}$ & 109 & 0.476 & NO \\
\hline & $(0.157)$ & $(0.127)$ & (0.570) & (1.158) & $(0.0750)$ & (0.197) & & & \\
\hline & $0.674^{* * * *}$ & $0.745^{* * *}$ & $1.676^{* * *}$ & $3.826^{* * *}$ & $-0.257^{* * *}$ & $0.580 * * *$ & 109 & 0.477 & YES \\
\hline & $(0.157)$ & $(0.128)$ & $(0.570)$ & $(1.155)$ & $(0.0790)$ & $(0.202)$ & & & \\
\hline
\end{tabular}


Table 6. Estimation Results with Additional Exogenous Shocks (continued)

(b). Without supply shocks: Type III

\begin{tabular}{|c|c|c|c|c|c|c|c|c|c|}
\hline & \begin{tabular}{|l|} 
Constant \\
term
\end{tabular} & $\begin{array}{l}\text { Real GDP } \\
\text { growth }\end{array}$ & $\begin{array}{l}\text { NY WTI } \\
\text { oil price } \\
\end{array}$ & $\begin{array}{l}\text { USD/Yen } \\
\text { rate } \\
\end{array}$ & $\begin{array}{l}\text { US GDP } \\
\text { growth }\end{array}$ & $\begin{array}{l}\text { China GDP } \\
\text { growth }\end{array}$ & $\#$ of obs. & R-squared & \begin{tabular}{|l|} 
Horizon \\
dummies
\end{tabular} \\
\hline \multirow[t]{4}{*}{$201106-12$} & $-0.975^{* * *}$ & $0.367^{* * * *}$ & $0.787^{* * *}$ & 0.780 & 0.0867 & -0.0324 & 238 & 0.401 & $\mathrm{NO}$ \\
\hline & $(0.128)$ & $(0.0590)$ & $(0.385)$ & $(0.589)$ & $(0.0595)$ & $(0.0331)$ & & & \\
\hline & $-0.633^{* * *}$ & $0.276^{* * *}$ & 0.416 & 0.607 & -0.0466 & -0.0371 & 238 & 0.499 & YES \\
\hline & $(0.142)$ & $(0.0602)$ & $(0.330)$ & $(0.582)$ & $(0.0576)$ & $(0.0303)$ & & & \\
\hline \multirow[t]{4}{*}{$201206-12$} & $-0.173^{* *}$ & $0.230^{* * *}$ & $0.717^{* * *}$ & $-1.867^{* * *}$ & 0.0747 & $0.0698^{*}$ & 230 & 0.316 & NO \\
\hline & $(0.0680)$ & $(0.0368)$ & $(0.201)$ & $(0.455)$ & $(0.0485)$ & $(0.0416)$ & & & \\
\hline & $-0.177^{* *}$ & $0.235^{* * *}$ & $0.755^{* * *}$ & $-1.794^{* * *}$ & 0.0631 & 0.0487 & 230 & 0.330 & YES \\
\hline & $(0.0724)$ & $(0.0385)$ & $(0.211)$ & $(0.465)$ & $(0.0491)$ & $(0.0427)$ & & & \\
\hline \multirow[t]{4}{*}{$201306-12$} & $0.219^{* * *}$ & $0.436^{* * *}$ & $1.456^{* * *}$ & $2.571^{* * *}$ & $0.184^{* * *}$ & 0.0537 & 237 & 0.255 & $\mathrm{NO}$ \\
\hline & $(0.0700)$ & $(0.0700)$ & $(0.476)$ & $(0.673)$ & $(0.0588)$ & $(0.0638)$ & & & \\
\hline & $0.219^{* * *}$ & $0.448^{* * *}$ & $1.379^{* * * *}$ & $2.553^{* * * *}$ & $0.179^{* * * *}$ & 0.0569 & 237 & 0.261 & YES \\
\hline & $(0.0728)$ & $(0.0762)$ & $(0.505)$ & (0.666) & $(0.0617)$ & $(0.0795)$ & & & \\
\hline \multirow[t]{4}{*}{$201406-12$} & $0.399 * * *$ & $0.457 * * *$ & $1.913^{* * *}$ & $2.059 * *$ & 0.136 & 0.00761 & 240 & 0.284 & NO \\
\hline & (0.118) & $(0.0714)$ & $(0.358)$ & (0.808) & (0.103) & (0.0963) & & & \\
\hline & $0.380^{* * *}$ & $0.472^{* * *}$ & $1.899^{* * * *}$ & $1.987^{* * *}$ & 0.133 & 0.00934 & 240 & 0.293 & YES \\
\hline & $(0.126)$ & $(0.0767)$ & $(0.491)$ & $(0.834)$ & $(0.105)$ & $(0.0969)$ & & & \\
\hline \multirow[t]{4}{*}{$201506-12$} & $0.513^{* * *}$ & $0.380^{* * *}$ & $0.724^{* *}$ & -0.987 & 0.189 & $0.311^{* * *}$ & 256 & 0.222 & $\mathrm{NO}$ \\
\hline & $(0.135)$ & $(0.0746)$ & $(0.316)$ & (1.189) & $(0.128)$ & (0.111) & & & \\
\hline & $0.529^{* * *}$ & $0.372^{* * *}$ & 0.572 & -0.891 & 0.165 & $0.296^{* * *}$ & 256 & 0.229 & YES \\
\hline & $(0.142)$ & $(0.0782)$ & $(0.356)$ & (1.208) & $(0.135)$ & $(0.111)$ & & & \\
\hline \multirow[t]{4}{*}{$201606-12$} & 0.117 & $0.177^{* * *}$ & $1.317^{* * *}$ & $2.720 * * *$ & $0.358^{* * *}$ & $0.170^{* *}$ & 254 & 0.337 & $\mathrm{NO}$ \\
\hline & $(0.0846)$ & $(0.0621)$ & $(0.257)$ & (0.668) & $(0.0932)$ & $(0.0736)$ & & & \\
\hline & 0.0644 & $0.221^{* * *}$ & $1.447^{* * *}$ & $3.631^{* * *}$ & $0.317^{* * * *}$ & $0.164^{* *}$ & 254 & 0.394 & YES \\
\hline & $(0.0830)$ & $(0.0605)$ & $(0.245)$ & $(0.752)$ & $(0.0842)$ & $(0.0728)$ & & & \\
\hline \multirow[t]{4}{*}{$201706-12$} & $0.418^{* * *}$ & $0.322^{* * *}$ & $2.276^{* * *}$ & $1.282^{* *}$ & $0.203^{* *}$ & 0.191 & 278 & 0.360 & $\mathrm{NO}$ \\
\hline & (0.118) & $(0.0716)$ & $(0.327)$ & (0.543) & $(0.0946)$ & (0.138) & & & \\
\hline & $0.487^{* * *}$ & $0.322^{* * *}$ & $2.503^{* * *}$ & $1.256^{* *}$ & $0.164^{*}$ & $0.326^{* *}$ & 278 & 0.403 & YES \\
\hline & (0.117) & $(0.0697)$ & $(0.330)$ & (0.559) & $(0.0914)$ & $(0.140)$ & & & \\
\hline
\end{tabular}


Table 6. Estimation Results with Additional Exogenous Shocks (continued)

(c). Without supply shocks: Type IV

\begin{tabular}{|c|c|c|c|c|c|c|c|c|c|}
\hline & Constant & Real GDP & NY WTI & USD/Yen & US GDP & China GDP & \# of obs. & R-squared & Horizon \\
\hline & term & growth & oil price & rate & growth & growth & & & dummies \\
\hline \multirow[t]{4}{*}{2012 01-05 } & $-0.590 * * *$ & $0.225^{* * *}$ & $0.836^{* * *}$ & $1.773^{* *}$ & -0.0269 & -0.00554 & 194 & 0.325 & $\mathrm{NO}$ \\
\hline & $(0.143)$ & $(0.0683)$ & $(0.217)$ & $(0.709)$ & $(0.0836)$ & $(0.0484)$ & & & \\
\hline & $-0.460 * * *$ & $0.178^{* * *}$ & $0.624^{* * *}$ & $1.406^{*}$ & -0.0200 & 0.0283 & 194 & 0.380 & YES \\
\hline & $(0.140)$ & $(0.0684)$ & $(0.237)$ & $(0.729)$ & $(0.0847)$ & $(0.0510)$ & & & \\
\hline \multirow[t]{4}{*}{2013 01-05 } & $-0.157^{*}$ & $0.135^{* * *}$ & $0.574^{* *}$ & $0.889 * * *$ & $0.162^{* * *}$ & $0.141^{* *}$ & 197 & 0.284 & $\mathrm{NO}$ \\
\hline & $(0.0831)$ & $(0.0510)$ & $(0.236)$ & $(0.330)$ & $(0.0531)$ & $(0.0614)$ & & & \\
\hline & -0.152 & $0.135^{* *}$ & $0.598^{* *}$ & $0.818^{*}$ & $0.165^{* * *}$ & $0.153^{* *}$ & 197 & 0.288 & YES \\
\hline & $(0.109)$ & $(0.0543)$ & $(0.248)$ & $(0.459)$ & $(0.0540)$ & $(0.0639)$ & & & \\
\hline \multirow[t]{4}{*}{2014 01-05 } & $0.649 * * *$ & $0.139 * *$ & 0.556 & $1.855^{* * *}$ & $0.157^{*}$ & 0.128 & 199 & 0.167 & $\mathrm{NO}$ \\
\hline & $(0.107)$ & (0.0669) & $(0.391)$ & $(0.650)$ & (0.0828) & $(0.105)$ & & & \\
\hline & $0.611^{* * *}$ & $0.163^{* *}$ & 0.488 & $1.940 * * *$ & $0.181^{* *}$ & 0.148 & 199 & 0.220 & YES \\
\hline & $(0.109)$ & $(0.0676)$ & $(0.402)$ & $(0.644)$ & $(0.0826)$ & $(0.105)$ & & & \\
\hline \multirow[t]{4}{*}{2015 01-05 } & $0.806^{* * *}$ & $0.131^{*}$ & $1.642^{* * *}$ & 0.0224 & $0.228^{* * *}$ & $0.360 * * *$ & 207 & 0.391 & $\mathrm{NO}$ \\
\hline & $(0.150)$ & $(0.0689)$ & $(0.191)$ & $(0.963)$ & $(0.0711)$ & $(0.129)$ & & & \\
\hline & $0.758^{* * *}$ & $0.140^{* *}$ & $1.400^{* * *}$ & 0.174 & 0.0334 & $0.234^{* *}$ & 207 & 0.461 & YES \\
\hline & $(0.169)$ & $(0.0649)$ & $(0.236)$ & $(0.880)$ & $(0.0938)$ & $(0.116)$ & & & \\
\hline \multirow[t]{4}{*}{2016 01-05 } & $0.612^{* * *}$ & 0.120 & $0.890 * * *$ & $2.411^{* * *}$ & 0.0455 & $0.387 * * *$ & 213 & 0.479 & $\mathrm{NO}$ \\
\hline & $(0.140)$ & $(0.0791)$ & $(0.184)$ & $(0.543)$ & $(0.0965)$ & $(0.0996)$ & & & \\
\hline & $0.480 * * *$ & $0.135^{*}$ & $0.737 * * *$ & 0.956 & -0.0510 & $0.395 * * *$ & 213 & 0.508 & YES \\
\hline & $(0.141)$ & $(0.0803)$ & $(0.232)$ & $(0.640)$ & $(0.0893)$ & $(0.0955)$ & & & \\
\hline \multirow[t]{4}{*}{2017 01-05 } & 0.114 & $0.310^{* * *}$ & $0.846^{* * *}$ & 0.617 & $0.244^{* * *}$ & -0.0489 & 209 & 0.253 & $\mathrm{NO}$ \\
\hline & $(0.126)$ & $(0.0724)$ & $(0.316)$ & $(0.469)$ & $(0.0720)$ & $(0.106)$ & & & \\
\hline & 0.114 & $0.308^{* * * *}$ & $0.827^{* *}$ & 0.614 & $0.248^{* * *}$ & -0.0533 & 209 & 0.254 & YES \\
\hline & $(0.129)$ & $(0.0769)$ & $(0.321)$ & $(0.466)$ & $(0.0803)$ & $(0.108)$ & & & \\
\hline \multirow[t]{4}{*}{2018 01-03 } & $0.493^{* *}$ & $0.413^{* * *}$ & $0.698^{* *}$ & 0.375 & 0.112 & $0.535^{* *}$ & 119 & 0.346 & $\mathrm{NO}$ \\
\hline & $(0.235)$ & $(0.124)$ & $(0.294)$ & $(0.760)$ & $(0.130)$ & $(0.224)$ & & & \\
\hline & $0.510^{* *}$ & $0.401^{* * *}$ & $0.817 * * *$ & -0.00519 & 0.120 & $0.564^{* *}$ & 119 & 0.349 & YES \\
\hline & $(0.235)$ & $(0.121)$ & $(0.280)$ & $(0.802)$ & $(0.134)$ & $(0.228)$ & & & \\
\hline
\end{tabular}

Note 1) Robust standard errors in parentheses.

2) *** $\mathrm{p}<0.01,{ }^{* *} \mathrm{p}<0.05,{ }^{*} \mathrm{p}<0.1$. 
Figure 1. The CPI inflation Rate in Japan

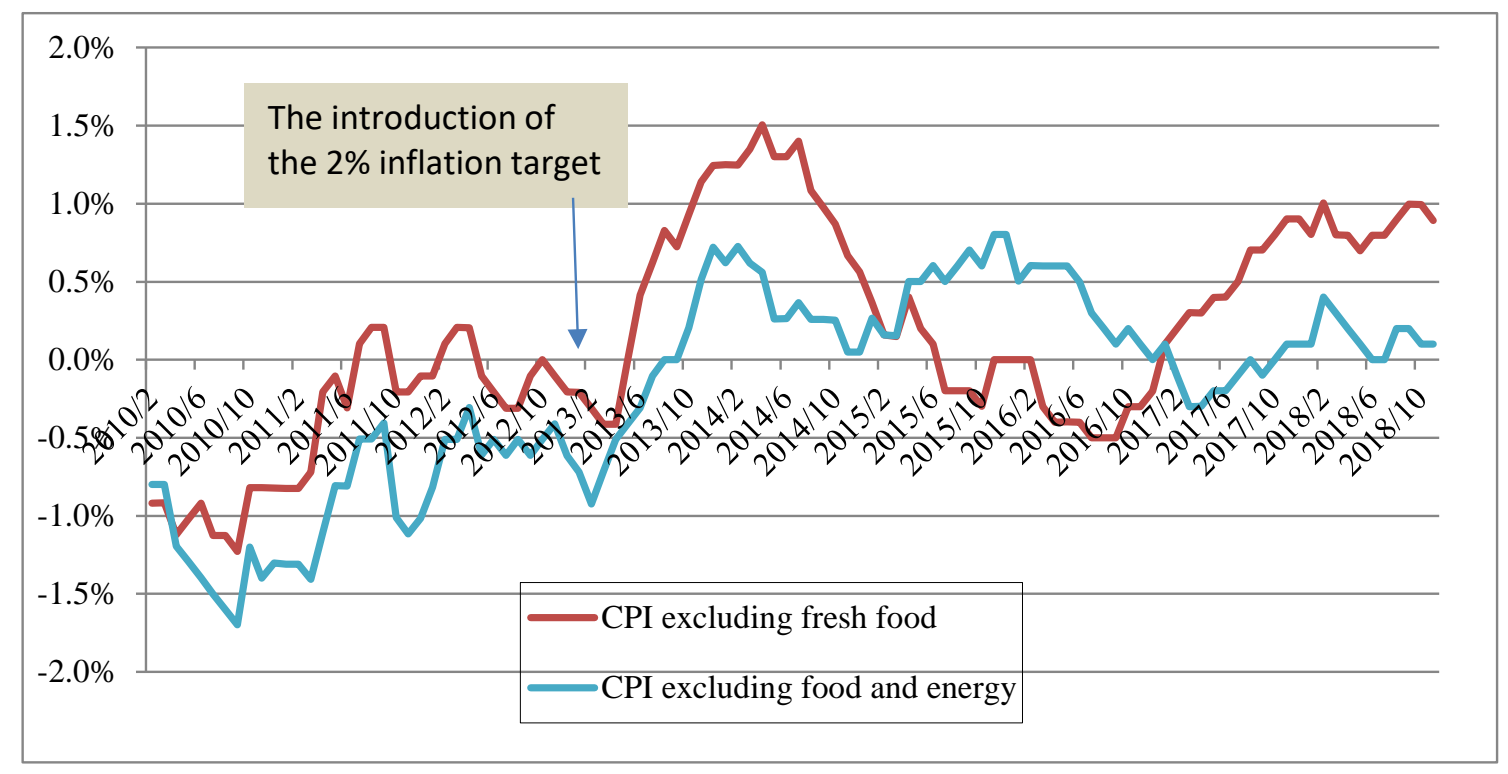

Note: The direct effects of consumption tax hikes are excluded in the inflation rates.

Source: Consumer Price Index, Statistics Bureau, Ministry of Internal Affairs and Communications. 
Figure 2. Estimated Anchor of Inflation Expectations: Basic Results

(1) Without controlling supply shocks

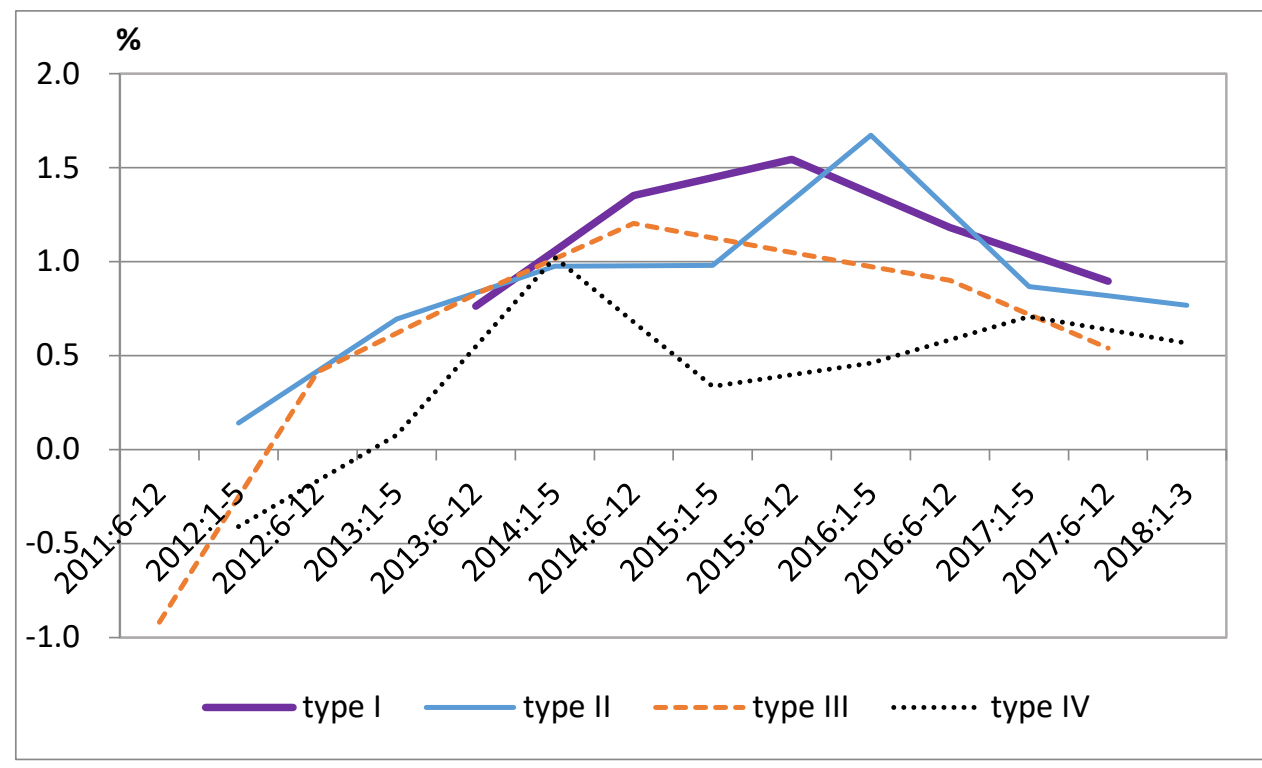

(2) With controlling supply shocks

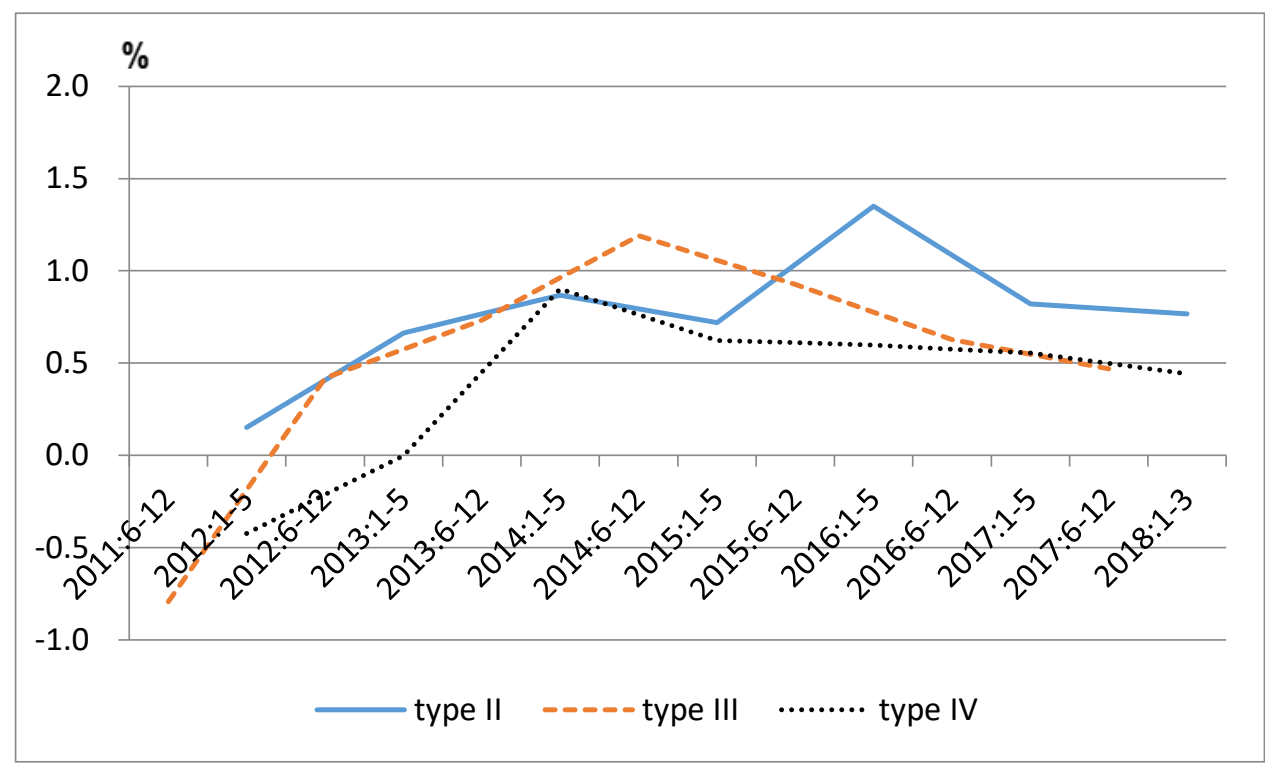

Note: The vertical axis is the estimated anchor of inflation expectations. 
Figure 3. Anchor of Inflation Expectations: With Instrumental Variables

(1) Without controlling supply shocks

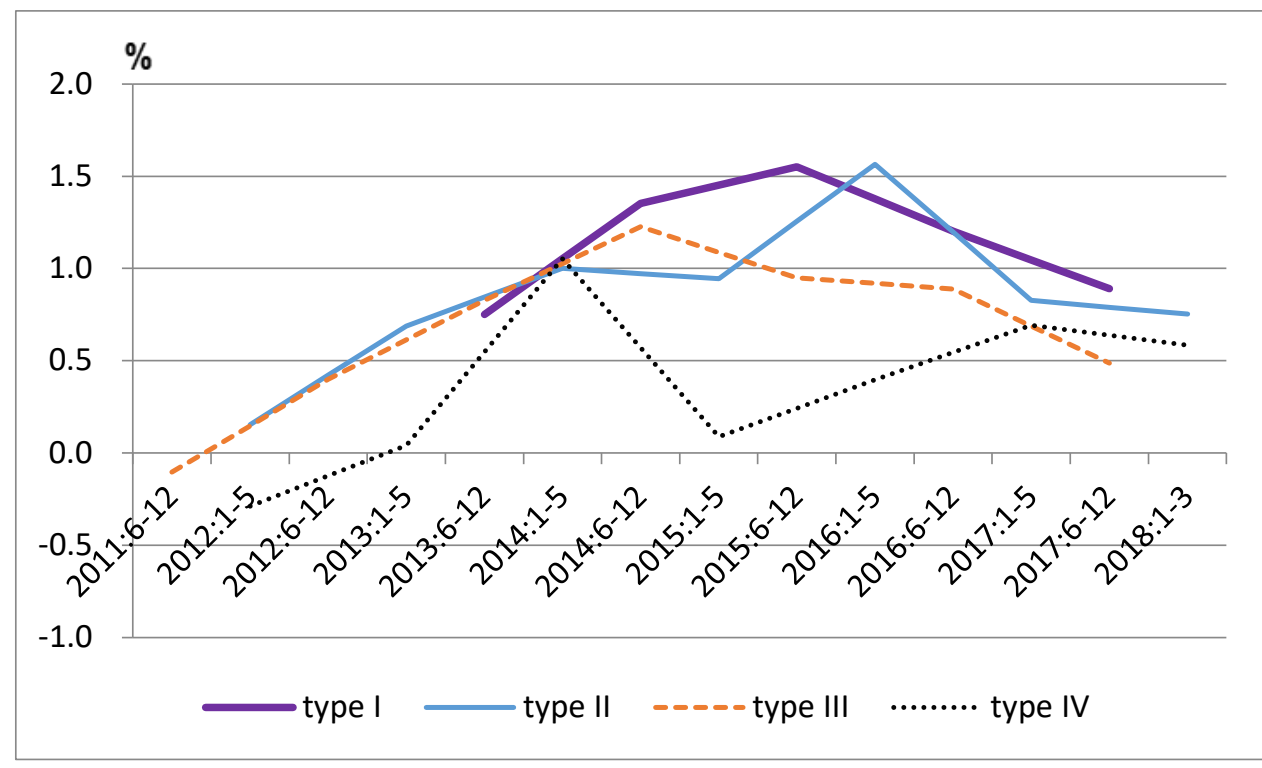

(2) With controlling supply shocks

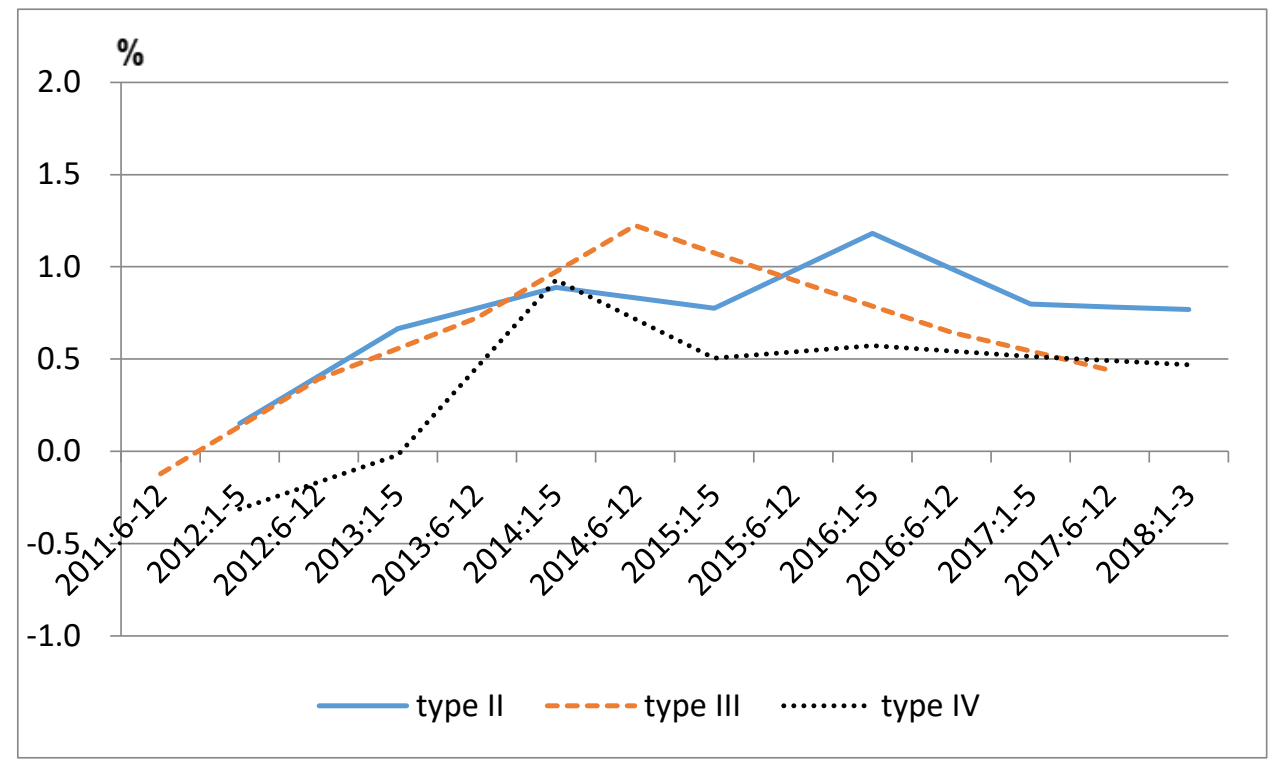

Note: The vertical axis is the estimated anchor of inflation expectations. 
Figure 4. Anchor of Inflation Expectations: With Additional Exogenous Variables

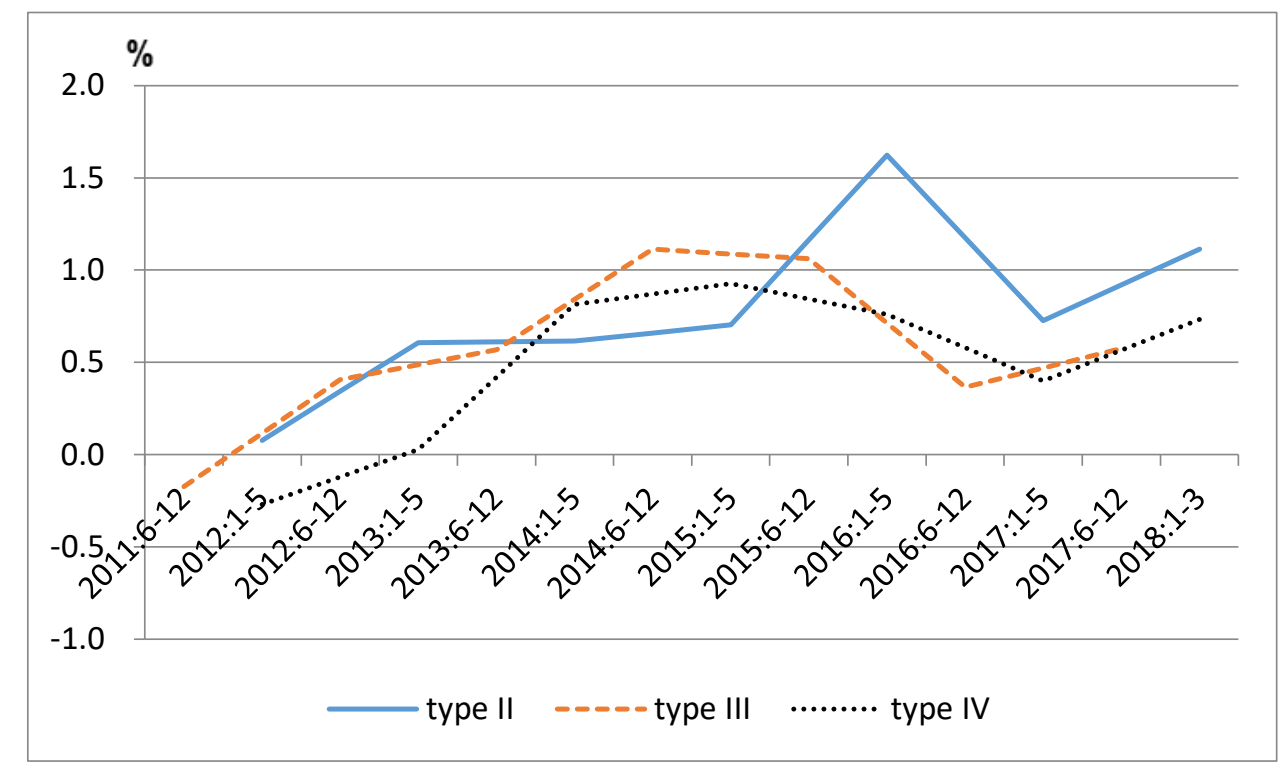

